\title{
Early and mid-Holocene climate in the tropical Pacific: seasonal cycle and interannual variability induced by insolation changes
}

\author{
Y. Luan ${ }^{1,2,3}$, P. Braconnot ${ }^{2}$, Y. Yu ${ }^{1}$, W. Zheng ${ }^{1}$, and O. Marti ${ }^{2}$ \\ ${ }^{1}$ State Key Laboratory of Numerical Modeling for Atmospheric Sciences and Geophysical Fluid Dynamics (LASG), \\ Institute of Atmospheric Physics (IAP), Beijing, China \\ ${ }^{2}$ Laboratoire des Sciences du Climat et de l'Environnement (LSCE/IPSL), UMR8212, CNRS-CEA-UVSQ, \\ Orme des Merisiers, Gif sur Yvette, France \\ ${ }^{3}$ Graduate University of Chinese Academy of Sciences, Beijing, China \\ Correspondence to: Y. Luan (yihua.luan@1sce.ipsl.fr)
}

Received: 16 January 2012 - Published in Clim. Past Discuss.: 6 February 2012

Revised: 23 May 2012 - Accepted: 30 May 2012 - Published: 29 June 2012

\begin{abstract}
Using a coupled atmosphere-ocean model we analyze the responses of the mean climate and interannual variations in the tropical Pacific to the changes in insolation during the early and mid-Holocene, with experiments in which only the variations of Earth's orbital configuration are considered. We first discuss common features of the Early and mid-Holocene climates compared to the pre-industrial conditions. In particular, an equatorial annual mean cooling that has a "U" shape across the tropical Pacific is simulated, whereas the ocean heat content is enhanced in the western tropical Pacific and decreased in the east. Similarly, the seasonality is enhanced in the west and reduced in the east. We show that the seasonality of the insolation forcing, the cloud radiative forcing and ocean dynamics all contribute to increasing these east-west contrasts. ENSO variability is reduced in the early Holocene and increases towards presentday conditions. Obliquity alone does not affect ENSO characteristics in the model. The reduction of ENSO magnitude results from the relationship between changes in seasonality, which involves wave propagation along the thermocline, and the timing of the development of ENSO anomalies. All these effects are larger in the Early Holocene compared to the mid-Holocene. Despite a one-month difference in the insolation forcing and corresponding response of SST, winds and thermocline depth between these two periods, the timing and changes in the east-west temperature and heat content gradients are similar. We suggest that it explains why the timing of development of ENSO is quite similar between these two climates and does not reflect the differences in the seasonal timing.
\end{abstract}

\section{Introduction}

The El Niño-Southern Oscillation (ENSO) phenomenon is the most important manifestation of short-term climate variability, resulting from air-sea interactions in the tropical Pacific (Philander, 1990). This coupled ocean-atmosphere mode impacts weather and climate patterns not only in the tropics but also in the extra-tropics, and is of vital importance for numerous countries (Ropelewski and Halpert, 1986; Lau and Nath, 2000; Wang et al., 2000; Annamalai et al., 2007). El Niño events develop every 2 to $7 \mathrm{yr}$ at present. During these events the anomalous westerly wind and deep convection are shifted toward the central equatorial Pacific Ocean and warm waters invade the equatorial cold tongue (Wang, 1992). Warm ENSO events have their cold counterpart - La Niña events. They have opposite characteristics resembling an enhancement of the normal conditions, with strengthening of the easterly trade wind and of the SST gradients across the equatorial Pacific. Analysis of the instrumental records shows that each event has its own characteristics. They also show that ENSO frequency increased in the last years of the twenty century, with the maximum SST anomalies located in the middle of the basin but not at the east coast as in the traditional view (Latif et al., 1997; Kao and Yu, 2009; Kug et al., 2009; Yeh et al., 2009). These changes appear to be connected to shifts in mean climate, raising the possibility that ENSO might undergo discernible changes in response to anthropogenic driven warming. However, even though most climate models now reproduce ENSO variability, there is no agreement on its future evolution (IPCC, 2007; Collins et al., 2010). Different models project a wide range of responses 
from weakened to enhanced ENSO (e.g. van Oldenborgh et al., 2005; Guilyardi, 2006; Merryfield, 2006). Some models do not show any significant difference in future ENSO (Collins et al., 2010). Changes in the mean state of the tropics are also uncertain, with models simulating responses ranging from "El Niño-like" to "La Niña-like" changes in tropical Pacific zonal SST gradients (e.g. Collins, 2005; Merryfield, 2006). There is thus a great need to further understand ENSO and how it is affected by changes in the background climate state. The understanding of past climate conditions provides a unique opportunity to achieve these goals.

Proxy reconstructions including oxygen isotope ratios and $\mathrm{Mg} / \mathrm{Ca}$ ratios in the Pacific Basin indicate that significant changes in the tropical Pacific mean climate state (e.g. Sandweiss et al., 1996; Koutavas et al., 2002; Stott et al., 2004; Lea et al., 2006) and ENSO characteristics (e.g. Rodbell et al., 1999; Tudhope et al., 2001; Moy et al., 2002; McGregor and Gagan, 2004) took place in the Holocene. Interannual variability of coral oxygen isotope and $\mathrm{Sr} / \mathrm{Ca}$ ratios at ENSO periods is found to be weaker in mid-Holocene coral than in modern coral from the same site, implying reduced ENSO amplitude (Tudhope et al., 2001; McGregor and Gagan, 2004). Rodbell et al. (1999) using a high-resolution $15000 \mathrm{yr}$ record of lake deposits in Ecuador suggests that strong ENSO events became established only from $5000 \mathrm{yr}$ ago. In addition, several other high-resolution records suggest reduced activity of ENSO (e.g. McGlone et al., 1992). Climate reconstructions based on different proxy indicators disagree widely on the changes of annual mean SST in tropical Pacific. Stott et al. (2004) using oxygen and $\mathrm{Mg} / \mathrm{Ca}$ data from foraminifers estimated that the SST decrease in SST of $0.5^{\circ} \mathrm{C}$ in the western tropical Pacific over the past $10000 \mathrm{yr}$. In the mid-Holocene, some reconstructions indicate that SST were warmer than today both in the western Pacific (Stott et al., 2004; McGlone et al., 1992) and in the eastern Pacific (Sandweiss et al., 1996). However, Koutavas et al. (2002) reports colder SST in the east Pacific compared to present day.

During the Holocene, the main forcing of the ENSO evolution is the changes in insolation seasonal cycle due to the precession and obliquity. The change in the timing of perihelion from boreal winter to boreal summer resulted in an increased Northern Hemisphere (NH) seasonal cycle, while reducing the strength of Southern Hemisphere (SH) seasonality (Berger, 1978). As a consequence of the increased NH seasonality, monsoon was enhanced in several regions (Wright et al., 1993; Liu et al., 2003). These monsoon changes have been widely analyzed with coupled models (e.g. Braconnot et al., 2007b). Several studies also explore the mechanism of ENSO changes in Holocene from coupled atmosphere-ocean model simulations (Table 1). Table 1 provides syntheses of the main findings. They pointed out that insolation change is the main factor that reduces the amplitude of the interannual variability through the influence of extra-tropical monsoon (Liu et al., 2000, 2003) and the Bjerknes feedback (Clement et al., 2000, 2001). Rodbell et al. (1999) suggested that the reduced SST gradient between the western Pacific warm pool and the eastern Pacific cold tongue mainly damp the ENSO development in the early to mid-Holocene. Results from an ensemble of mid-Holocene simulations run with different climate models as part of the second phase of Paleoclimate Modeling Intercomparison Project (PMIP2) also show a reduced ENSO amplitudes at $6 \mathrm{ka}$ than at present (Zheng et al., 2008).

Above all, most previous studies using coupled models focused on the ENSO characteristics in the mid-Holocene. Only a few studies considered the changes in mean state and interannual variability in the early Holocene and compared the early Holocene with the mid-Holocene, even though results from transient simulations have become available (Timmermann et al., 2007). In addition, there is still a need to better understand the mechanism by which the local insolation affects the tropical Pacific climate through the surface radiative fluxes and dynamical process. Recently, Braconnot et al. (2012) used the climate system model IPSL_CM4 to study the relative influence of the orbitally-driven changes and a fresh water flux in the North Atlantic on the climate seasonal cycle and interannual variability changes. They show that the insolation forcing affects both the tropical Pacific SST seasonal cycle and ENSO characteristics and that the resulting changes have a larger magnitude than that the changes induced by a fresh water flux release in the north Atlantic. They also discussed the fact that Holocene SST changes are dominated by changes in seasonality in most of the tropical Pacific. In this study, we only consider the early and midHolocene insolation in simulations to analyze in more depth the changes in mean seasonal cycle and interannual variability changes induced by insolation changes. In particular we link the changes in SST and in ocean stratification to the insolation forcing, considering the surface radiative fluxes. As modern ENSO is observed to be strongly phase-locked to the seasonal cycle (Wang and Picaut, 2004), it might be expected that such a change in the seasonal cycle would alter the behavior of ENSO in the Holocene. We thus also highlight some of the differences between early Holocene and mid-Holocene, considering the phase relationship between the development of the ENSO events and the seasonal evolution of the background mean state. The relative roles of the obliquity and precession are further explored considering a sensitivity experiment to the early Holocene obliquity.

The paper is organized as follows: climate simulations and analyses are first described in Sect. 2. Sections 3 and 4 analyze the characteristics of the pre-industrial climate and the simulated changes for the early and mid-Holocene. The role of the obliquity is discussed in Sect. 5. Discussion and conclusions are presented in Sect. 6. 
Table 1. Summary of previous paleo-ENSO simulations for the Holocene.

\begin{tabular}{llll}
\hline Authors & Model & Periods & Conclusions \\
\hline $\begin{array}{l}\text { Clement et al. } \\
(1999,2000,\end{array}$ & $\begin{array}{l}\text { Zebiak-Cane } \\
\text { model (Zebiak } \\
\text { and Cane, } \\
\text { 1987) }\end{array}$ & Mid-Holocene & $\begin{array}{l}\text { The changes of tropical Pacific climate } \\
\text { over the mid- to late Holocene is largely } \\
\text { induced by orbitally driven changes in the } \\
\text { seasonal cycle of solar radiation in the tropics }\end{array}$ \\
\hline Bush (1999) & $\begin{array}{l}\text { GFDL AGCM } \\
\text { (Gordon and } \\
\text { Stern, 1982) }\end{array}$ & 6 ka & $\begin{array}{l}\text { A coupled AOGCM produce enhanced } \\
\text { Pacific upwelling, a more pronounced cold } \\
\text { tongue, and an even stronger monsoon. The } \\
\text { climate of the equatorial Pacific was more } \\
\text { similar to the La Niña phase of the modern } \\
\text { Southern Oscillation }\end{array}$
\end{tabular}

\begin{tabular}{|c|c|c|c|}
\hline $\begin{array}{l}\text { Liu et al. } \\
(1999,2000)\end{array}$ & $\begin{array}{l}\text { FOAM } \\
(\text { Jacob, 1997) }\end{array}$ & $\begin{array}{l}\text { Early and } \\
\text { mid-Holocene } \\
(11 \mathrm{ka} \text { and } 6 \mathrm{ka})\end{array}$ & $\begin{array}{l}\text { ENSO intensity reduced by both an } \\
\text { intensified Asian summer monsoon and a } \\
\text { south Hemisphere warm water subduction } \\
\text { caused by insolation changes }\end{array}$ \\
\hline $\begin{array}{l}\text { Otto-Bliesner } \\
\text { et al. }(2003)\end{array}$ & $\begin{array}{l}\text { CSM } \\
\text { (Otto-Bliesner } \\
\text { and Brady, 2001) }\end{array}$ & $\begin{array}{l}\text { Early Holocene } \\
\text { (11 ka) }\end{array}$ & $\begin{array}{l}\text { Model predicted weaker El Niños/La Niñas } \\
\text { compared to present for the Holocene and } \\
\text { stronger El Niños/La Niñas for the LGM. }\end{array}$ \\
\hline $\begin{array}{l}\text { Brown et al. } \\
(2006,2008 a, b)\end{array}$ & $\begin{array}{l}\text { HadCM3 } \\
\text { (Collins et al., } \\
\text { 2001) }\end{array}$ & $6 \mathrm{ka}$ & $\begin{array}{l}\text { The model simulates a smaller reduction in } \\
\text { ENSO amplitude of around } 10 \% \text {, and it } \\
\text { also simulates a slight shift to longer period } \\
\text { variability and a weakening of ENSO } \\
\text { phase-locking to the seasonal cycle in the } \\
\text { mid-Holocene. }\end{array}$ \\
\hline $\begin{array}{l}\text { Zheng et al. } \\
(2008)\end{array}$ & $\begin{array}{l}\text { PMIP2 } \\
\text { models }\end{array}$ & $\begin{array}{l}\text { Mid-Holocene } \\
(6 \mathrm{ka})\end{array}$ & $\begin{array}{l}\text { Results from an ensemble of mid-Holocene } \\
\text { simulations run with different climate } \\
\text { models as part of PMIP } 2 \text { show a reduced } \\
\text { simulated El Niño amplitudes at } 6 \text { ka than } \\
\text { at present }\end{array}$ \\
\hline $\begin{array}{l}\text { Chiang et al. } \\
(2009)\end{array}$ & $\begin{array}{l}\text { CCM3 (Kiehl } \\
\text { et al., 1998) }\end{array}$ & Mid-Holocene & $\begin{array}{l}\text { The mid-Holocene ENSO reduction was in } \\
\text { response to Pacific-wide climate changes } \\
\text { to mid-Holocene orbital conditions }\end{array}$ \\
\hline $\begin{array}{l}\text { Braconnot et al. } \\
(2012)\end{array}$ & $\begin{array}{l}\text { IPSL_CM4 } \\
\text { (Marti et al., 2010) }\end{array}$ & $\begin{array}{l}0 \mathrm{ka}, 6 \mathrm{ka} \\
\text { and } 9.5 \mathrm{ka}\end{array}$ & $\begin{array}{l}\text { The insolation forcing affects both the } \\
\text { tropical Pacific SST seasonal cycle and } \\
\text { ENSO characteristics and the resulting } \\
\text { changes have a larger magnitude than that } \\
\text { the changes induced by a fresh water flux } \\
\text { release in the North Atlantic. Holocene SST } \\
\text { changes are dominated by changes in } \\
\text { seasonality in most of the tropical Pacific. }\end{array}$ \\
\hline
\end{tabular}

\section{Climate simulations and analyses}

\subsection{Model description}

We consider the simulations of the pre-industrial, the midHolocene (6 ka BP) and the early Holocene (9.5 ka BP) discussed in Marzin and Braconnot (2009) and Braconnot et al. (2012). These simulations were run using the coupled ocean-atmosphere general circulation model IPSL_CM4 (Marti et al., 2010). The version is the same as the one used for CMIP3 experiments (Meehl et al., 2007) that served as a basis for the Fourth IPCC Assessment Report (IPCC AR4) (Solomon et al., 2007). It contains four components. The atmospheric component is the grid point atmospheric general circulation model LMDZ (Hourdin et al., 2006) developed at Laboratoire de Météorologie Dynamique (LMD, France). It has a resolution of 96 grid points in longitude, 72 grid points in latitude and 19 vertical levels. The oceanic component is the oceanic general circulation model ORCA (Madec 
et al., 1998) developed at the Laboratoire d'Océanographie et du Climat (LOCEAN, France) with the resolution of 182 points in longitude, 149 points in latitude and 31 vertical levels. The ORCA model uses the OPA (Océan PArallélisé) system (Madec et al., 1998) for ocean dynamics. The land surface scheme is ORCHIDEE (Krinner et al., 2005) and only the thermodynamics and hydrological components are active in the simulation here. Vegetation types and leaf area index are thus prescribed to their modern conditions. A river runoff scheme is used to close the fresh water budget between land and ocean. The sea-ice model LIM (Fichefet and Maqueda, 1997 ) is included in the ocean model to compute sea ice dynamics and thermodynamics. The ocean and atmosphere are coupled using the OASIS coupler (Terray et al., 1995) once a day and there is no flux correction at the air-sea interface.

\subsection{Experiments}

The PI simulation (pre-industrial period: $0 \mathrm{kaBP}$ ) was carried out using modern orbital parameters, vegetation coverage, continental ice sheets and topography. The greenhouse gases were set to pre-industrial (around 1750) concentrations (i.e. $\mathrm{CO}_{2}: 280 \mathrm{ppm}, \mathrm{CH}_{4}: 760 \mathrm{ppb}, \mathrm{N}_{2} \mathrm{O}: 270 \mathrm{ppb}$ ) (http:// pmip2.1sce.ipsl.fr/). The simulation is more than $1000 \mathrm{yr}$ long and is stable (the global surface temperature trend is less than $0.02 \mathrm{~K} /$ century, Marti et al., 2010). The initial state of the ocean is rest, with temperature and salinity prescribed from Levitus's (1983) climatology. A 1st January of the ERA15 reanalysis data from ECMWF is used as initial state for the atmosphere. The state of the soil is initialized with a water content of $300 \mathrm{~mm}$, and no snow cover (Marzin and Braconnot, 2009; Marti et al., 2010). The model was first adjusted for several centuries before running the PI simulation.

The MH simulation (mid-Holocene: $6 \mathrm{ka} \mathrm{BP}$ ) and EH simulation (early Holocene: $9.5 \mathrm{kaBP}$ ) were forced with the same continental ice sheets and topography as in the PI simulation but account for the changes in the Earth's orbital parameters (Marzin and Braconnot, 2009). The orbital parameters were prescribed from Berger (1978). The MH simulation corresponds to the PMIP2 simulation and also accounts for small changes in greenhouse gases following PMIP2 recommendations $\left(\mathrm{CO}_{2}: 280 \mathrm{ppm}, \mathrm{CH}_{4}: 650 \mathrm{ppb}\right.$ and $\mathrm{N}_{2} \mathrm{O}$ : $270 \mathrm{ppb}$ ) (Braconnot et al., 2007b, http://pmip2.1sce.ipsl.fr/). The greenhouse gases concentrations in the EH simulation are kept to the pre-industrial values. The global mean energetic in the model is only slightly affected by the changes in orbital parameters; the annual mean change of the insolation is negligible $\left(0.011 \mathrm{~W} \mathrm{~m}^{-2}\right)$ when averaged globally. It induces, however, a more than $30 \mathrm{~W} \mathrm{~m}^{-2}$ change in seasonal insolation. Simulations for the 6 and $9.5 \mathrm{ka} \mathrm{BP}$ climates are 650 and $500 \mathrm{yr}$ long, respectively. The initial state is the same as the one of the PI simulation. The model adjusts in 60 to $100 \mathrm{yr}$ to the new boundary conditions.

We also consider another sensitivity experiment (EHOB) in which the orbital parameters are prescribed to those of pre-industrial simulation, except obliquity that is set to its early Holocene value $(\varepsilon=24.231)$ as in the EH simulation. The EHOB simulation was forced with the same greenhouse gases concentration, vegetation coverage, continental ice sheets and topography as in the PI simulation. The experiment is $440 \mathrm{yr}$ long and we consider the last $229 \mathrm{yr}$ computing the climatological seasonal cycle.

All simulations were run long enough to be representative of an equilibrium climate. For the analysis, we use monthly time series from the last part of the simulations where the climate characteristic is stable. This corresponds to $770 \mathrm{yr}$ for the PI simulation and varies from 370 to $219 \mathrm{yr}$ for the $\mathrm{EH}$ and $\mathrm{MH}$ simulations, respectively, as discussed in Braconnot et al. (2012).

\section{Characteristics of the pre-industrial climate}

\subsection{Large scale features and seasonality}

The coupled model IPSL_CM4 captures the large-scale features of the tropical circulation (Braconnot et al., 2007a, b; Marti et al., 2010). The annual mean large-scale distribution of SST is well reproduced, such as the warm pool in the western Pacific and the equatorial cold tongue in the eastern Pacific compared to the HadiSST data (Rayner et al., 2003) (Fig. 1). But the equatorial cold tongue is too equatorially confined, and extends too far west into the western Pacific. This is associated with too strong wind stress and leads to a westward shift and an erosion of the warm pool. In the tropical Pacific, the east-west SST gradient is correctly represented, except for a warm bias along the coast of Peru and Chile. It results from the combination of insufficient wind along South America, the misrepresentation of cloud cover and the presence of a too developed double ITCZ structure in the eastern Pacific. The structure of the South Pacific Convergence Zone (SPCZ) is too zonal and penetrates too far toward the east Pacific (Marti et al., 2010), which is associated with excessive precipitation over much of the tropics. The pattern of precipitation is consistent with the temperature field (Braconnot et al., 2007a, b).

The seasonal cycle in the east Pacific in IPSL_CM4 is quite well represented compared to the other CMIP3 models, both in phase and amplitude (Marti et al., 2010). The annual cycle of SST simulated for the pre-industrial period in the eastern equatorial Pacific is consistent with the observation, but its phase is delayed about one month (Braconnot et al., 2012). The SST variability extends correctly from the east; however, its westward extension is slightly underestimated. The amplitude of the annual cycle (difference between maximum and minimum SST values) is also slightly weaker than observed.

\subsection{ENSO characteristics}

The IPSL_CM4 model simulates a larger variability and higher frequency than observed (about $2.7 \mathrm{yr}$ vs. $4-5 \mathrm{yr}$ in 


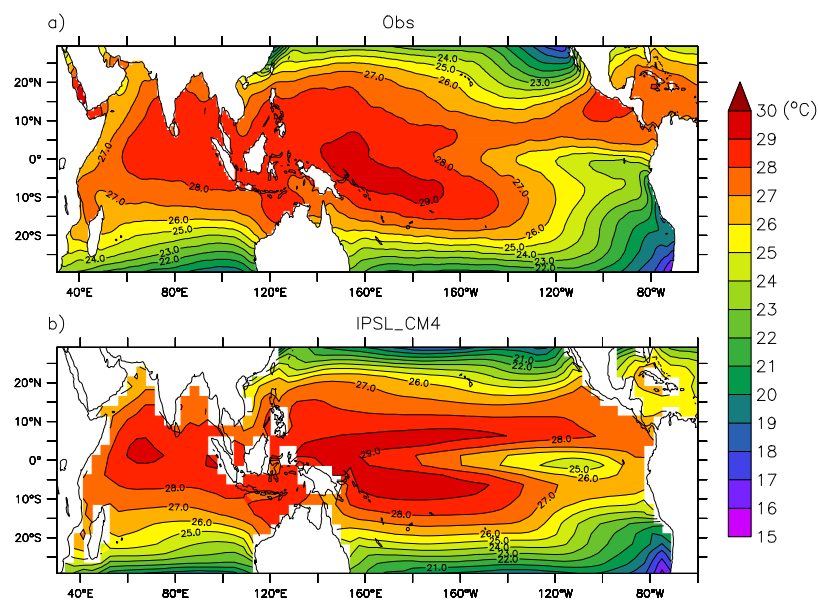

Fig. 1. Annual mean SST $\left({ }^{\circ} \mathrm{C}\right)$ distributions in the tropical Pacific and Indian Ocean: (a) Observed Climatology HadiSST data from 1870 to 2003 and (b) IPSL_CM4 PI simulation.

observations, Zheng et al., 2008). The ENSO amplitude is about right but the processes of damping ENSO in the model are too weak (Guilyardi et al., 2009; Marti et al., 2010). However, the model's tropical and ENSO simulations have consistently been ranked among the world's top GCMs in different comparisons with other CMIP3 simulations (van Oldenborgh et al., 2005; Guilyardi, 2006; Reichler and Kim, 2008).

In order to analyze the changes of tropical Pacific interannual variability, we consider the typical El Niño and La Niña events from each simulation and observed data (HadiSST data from 1870 to 2003) that are discussed in Braconnot et al. (2012). In each simulation, a year is considered as an El Niño (La Niña) year if the December-JanuaryFebruary (DJF) average of Niño3 index (an average of the SST anomaly in the region $150^{\circ} \mathrm{W}-90^{\circ} \mathrm{W}, 5^{\circ} \mathrm{S}-5^{\circ} \mathrm{N}$ ) exceeds 1.2 times its standard deviation $(1.2 \sigma)$. We only discuss in the following robust features. Details of the statistical analyses can be found in Braconnot et al. (2012)

Figure 2 shows the evolution of the composite SST, precipitation and wind stress anomalies during El Niño years minus mean state in the PI simulation, considering every two months from June preceding the peak of the event to the following April. This figure also compares the evolution of SST anomaly in the PI simulation with that in HadiSST data. El Niño simulated onset occurs from June in the eastern part of the basin as observed. It is associated with a convergent wind over the warm SST anomalies, as well as increased precipitation along the equator and decreased precipitation on both sides of the equator. Then the convergent wind stress becomes stronger and damps the oceanic upwelling in the middle and eastern tropical Pacific. The positive SST anomalies intensify reaching its peak at the end of the El Niño year. The enhancement of precipitation anomaly occurs in the central and eastern Pacific (Fig. 2). The positive SST anomalies decrease after the El Niño year. The model reproduces the
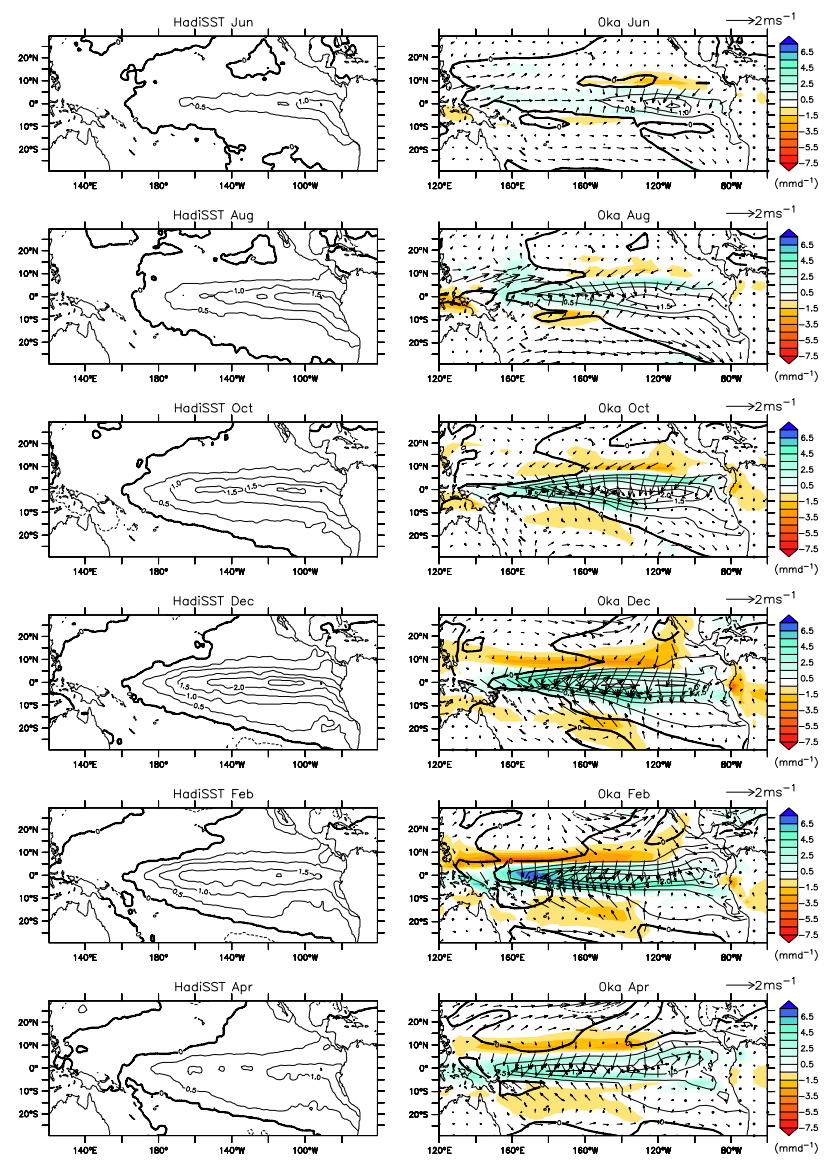

Fig. 2. Time evolution of SST (line, ${ }^{\circ} \mathrm{C}$ ), precipitation (color, $\mathrm{mm} \mathrm{d}^{-1}$ ) and wind stress anomalies (arrow, $\mathrm{m} \mathrm{s}^{-1}$ ) during a composite El Niño year (see details of the composite analysis in the text) minus mean state for the PI simulation (right), and for HadiSST data (left).

SST feature, but its spatial structure extends too far to the west and is too confined around the equator. No clear relationship is found between this bias and the characteristics of the model mean state bias in the equatorial Pacific. Leloup et al. (2008) have shown that this bias is mainly related to a misrepresentation of both El Niño and La Niña termination phases for most of the CMIP3 simulations. Guilyardi (2006), however, suggested that this classical bias of coupled models is related to too strong mean zonal wind stress. In the observation, ENSO maximum amplitude occurs in the centraleastern Pacific. But the standard deviation of air temperature increases from the western Pacific to the eastern Pacific Ocean (AchutaRao and Sperber, 2006). The SST anomalies averaged over the Niño3 or Niño3.4 regions are then usually used to describe ENSO. IPSL_CM4 model simulates the maximum El Niño amplitude in the same area as the observations, even though the maximum is too strong in the Niño3.4 region (Fig. 2). 


\section{Simulated changes for the early and mid-Holocene}

\subsection{Changes in Insolation}

During the early and mid-Holocene, changes of insolation due to slow variations of the Earth's orbital parameters are the major drivers of climate variability (Marzin and Braconnot, 2009). Figure 3 shows the incoming solar radiation $\left(\mathrm{W} \mathrm{m}^{-2}\right)$ at the top of the atmosphere. As a consequence of precession, which shifts the timing of perihelion from boreal winter to boreal summer in the early Holocene, the early and mid-Holocene were characterized by an enhanced seasonal cycle in the $\mathrm{NH}$, while reduced seasonality in the $\mathrm{SH}$ (Fig. 3b, d) as the previous study (Berger, 1978). Along the equator (averaged from $5^{\circ} \mathrm{S}$ to $5^{\circ} \mathrm{N}$ and removed annual mean), insolation is zonally uniform and exhibits a semi-annual cycle with two maxima respectively in spring and autumn in the PI simulation (Fig. 3c). In the early Holocene, insolation is amplified by almost $30 \mathrm{~W} \mathrm{~m}^{-2}$ during boreal summer and the maximum and minimum changes are in phase with the summer and winter solstices. The superposition of this annual mean cycle with the semi-annual cycle damps the boreal winter insolation forcing and strengthens the boreal summer insolation and the autumn maximum forcing. A similar pattern is found for the mid-Holocene, with a maximum amplification of about $25 \mathrm{~W} \mathrm{~m}^{-2}$. There is a lag of about one month compared with the $9.5 \mathrm{ka} \mathrm{BP}$ signal (Fig. 3c). Because the lengths of the seasons are altered by the precession variations, the calendar we used for the monthly average have a slight effect on the study (Joussaume and Braconnot, 1997). But it does not change the major conclusion.

\subsection{Impact of orbital forcing on the surface radiative fluxes}

The insolation forcing drives the changes in the annual mean surface radiative fluxes (Table 2). Surface radiative fluxes include the net solar radiation (SW), the net longwave radiation (LW), the latent heat flux (LE), the sensible heat flux (Hs), and the net radiative flux (surface budget (to$\mathrm{tal})=\mathrm{SW}+\mathrm{LW}+\mathrm{LE}+\mathrm{Hs}$, all fluxes are positive downward). In the PI simulation, as in the modern climate, the annual mean net radiative flux is much larger in the eastern Pacific where the thermocline is shallower than in the western Pacific (Table 2) stressing that the dynamical cooling, resulting from zonal and meridional ocean heat transports, plays a large role in these regions to balance the surface fluxes (Clement et al., 1996). As shown in Table 2, the net solar radiation in the two regions is mainly balanced by long wave and latent heat fluxes. However, the magnitude of the latent heat is larger over the warm water in the warm pool region. The difference in cloud cover and SST across the Pacific also explains that the net surface SW is smaller in the warm pool and the LW is smaller in the cool tongue (Table 2).
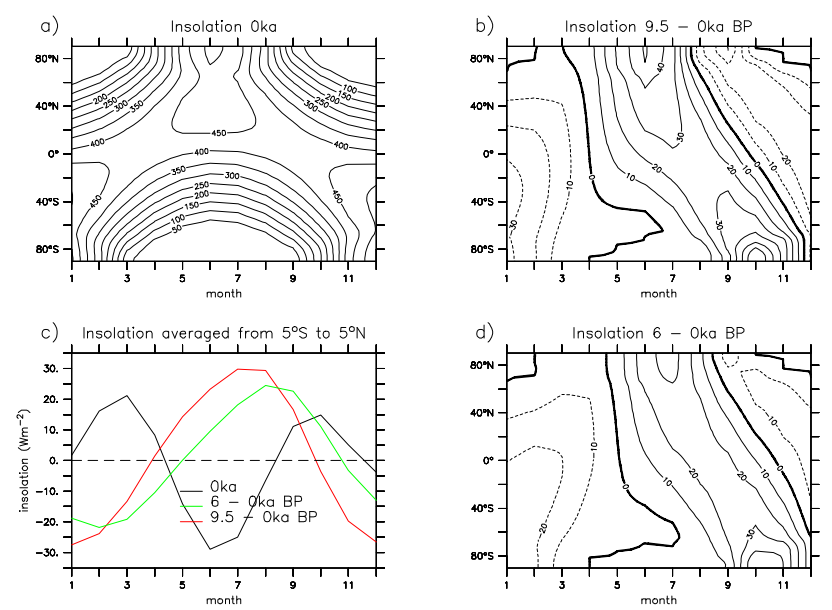

Fig. 3. Incoming solar radiation $\left(\mathrm{W} \mathrm{m}^{-2}\right)$ at the top of the atmosphere plotted as a function of months and latitude for (a) $0 \mathrm{ka} \mathrm{BP}$, (b) $9.5-0 \mathrm{ka} \mathrm{BP}$, (d) 6-0 ka BP; (c) insolation averaged from $5^{\circ} \mathrm{S}$ to $5^{\circ} \mathrm{N}$ (annual mean removed) and plotted as a function of months for $0 \mathrm{ka}$ (black line), 6-0 ka BP (green line) and 9.5-0 ka BP (red line).

Table 2. Annual mean radiative flux of the PI simulation in the western Pacific (WP: $140^{\circ} \mathrm{E}-180^{\circ} \mathrm{E}, 5^{\circ} \mathrm{S}-5^{\circ} \mathrm{N}$ ) and the Niño3 box $\left(150^{\circ} \mathrm{W}-90^{\circ} \mathrm{W}, 5^{\circ} \mathrm{S}-5^{\circ} \mathrm{N}\right)$ (unit: $\mathrm{W} \mathrm{m}^{-2}$, positive downward).

\begin{tabular}{llrrrrr}
\hline & & TOTAL & SW & LW & Hs & LE \\
\hline \multirow{2}{*}{$0 \mathrm{ka}$} & WP & 32.71 & 232.90 & -73.25 & -14.85 & -112.37 \\
& Niño3 & 92.33 & 249.72 & -59.43 & -10.15 & -87.80 \\
$6 \mathrm{ka}$ & WP & 36.02 & 237.82 & -74.68 & -15.02 & -112.40 \\
& Niño3 & 91.53 & 250.70 & -59.98 & -10.40 & -88.79 \\
$9.5 \mathrm{ka}$ & WP & 37.90 & 240.72 & -75.40 & -15.09 & -112.63 \\
& Niño3 & 91.15 & 250.15 & -60.15 & -10.46 & -88.39 \\
\hline
\end{tabular}

The seasonal cycle of the surface radiative fluxes (annual mean removed) is shown in Fig. 4. It focuses on the western Pacific (solid line) and eastern Pacific (dash line), respectively. In the PI simulation, the net radiative fluxes on both sides of the basin follow the semi-annual insolation forcing (Fig. 3c) and exhibits two peaks in spring and autumn (Fig. 4a). Even through the insolation forcing is zonally uniform along the tropical Pacific, the seasonal timing of the maximum and minimum heat fluxes at surface are different in the western Pacific and eastern Pacific (Fig. 4a). Clement et al. (1999) illustrated that the background seasonal cycle in the wind divergence field is responsible for converting the zonally uniform solar forcing into a zonally asymmetric response. They showed that a uniform heating, which approximates the processional forcing, will initially generate a uniform SST anomaly that affect the atmosphere differently in different seasons because of the background seasonal cycle in the wind divergence field. However, they ignored the effect of cloud radiative forcing $(\mathrm{CRF})$.

We calculated the annual mean shortwave CRF and seasonal evolution of the shortwave and longwave CRFs, using 


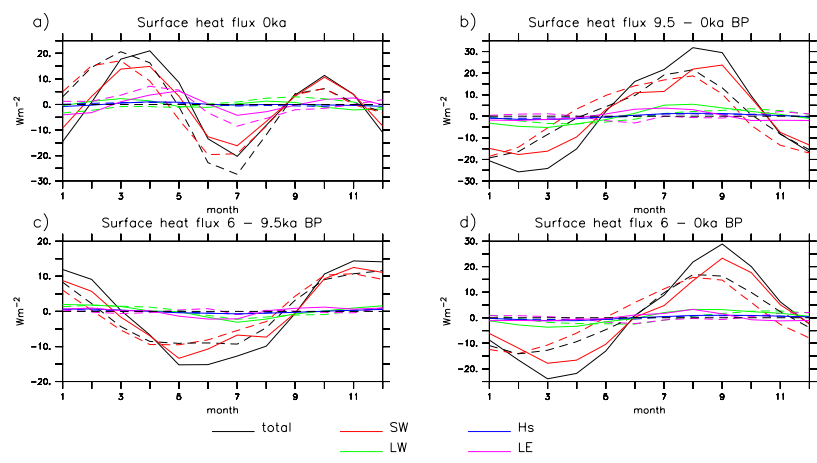

Fig. 4. Changes in the seasonal evolution of surface radiative flux $\left(\mathrm{W} \mathrm{m}^{-2}\right)$ (annual mean removed) for the western Pacific $\left(140^{\circ} \mathrm{E}-\right.$ $\left.180^{\circ} \mathrm{E}, 5^{\circ} \mathrm{S}-5^{\circ} \mathrm{N}\right)$ (solid line) and the eastern Pacific $\left(90^{\circ} \mathrm{W}-\right.$ $150^{\circ} \mathrm{W}, 5^{\circ} \mathrm{S}-5^{\circ} \mathrm{N}$ ) (dash line) for (a) $0 \mathrm{ka} \mathrm{BP}$, (b) $9.5-0 \mathrm{ka} \mathrm{BP}$, (d) 6-0 ka BP and (c) 6-9.5 ka BP. Surface radiative fluxes include the net solar radiation (SW), the net longwave radiation (LW), the latent heat flux (LE), the sensible heat flux (Hs), and the net heat flux (surface budget $($ total $)=\mathrm{SW}+\mathrm{LW}+\mathrm{LE}+\mathrm{Hs}$, all fluxes are positive downward).

the downward shortwave and longwave fluxes at the surface in the cloudy sky minus those in the clear sky and compare them with the ISCCP data (Zhang et al., 2004) from 1984 to 1999 in Fig. 5. The annual mean shortwave CRF mainly weakens the shortwave radiation. The pattern of the cloud shortwave radiation is well simulated in the tropical Pacific. However, to the north of the equator, the signature of the CRF on the ITCZ region is too pronounced in the western tropical Pacific and underestimated in the eastern Pacific. The lack of marine stratocumulus clouds in the northeast part of the tropical Pacific is a major issue. To the south of the equator, the CRF effect is reasonably simulated between $0^{\circ}$ and $5^{\circ} \mathrm{S}$ but it is strongly underestimated along the Peru and Chile coast. The effect of clouds is maximal in the western tropical Pacific from November to March, reducing the net solar radiation at the surface, while such an effect is small in boreal summer. In the eastern Pacific, the maximum effect of clouds on the shortwave radiation occurs in autumn. During the first half of the year, the differences in shortwave CRF between the west and the east is consistent with the different timing in the net shortwave radiation at the surface, that is characterized by a radiative cooling in the west when the east reverses to minimum cloud effect (Fig. 5). The seasonal variation of the net longwave radiative forcing is small in the western tropical Pacific and enhances in the eastern tropical Pacific in autumn.

Compared to the PI simulation, changes in insolation during the early and mid-Holocene causes a decrease of the net total heat flux in boreal winter and an increase in summer in the western and eastern tropical Pacific (Fig. 4b, d). In the $\mathrm{EH}$ and $\mathrm{MH}$ simulations, the magnitude of the seasonal cycle changes in the net heat flux is larger than that in the net solar radiation, which stresses that SST, water vapor and cloud
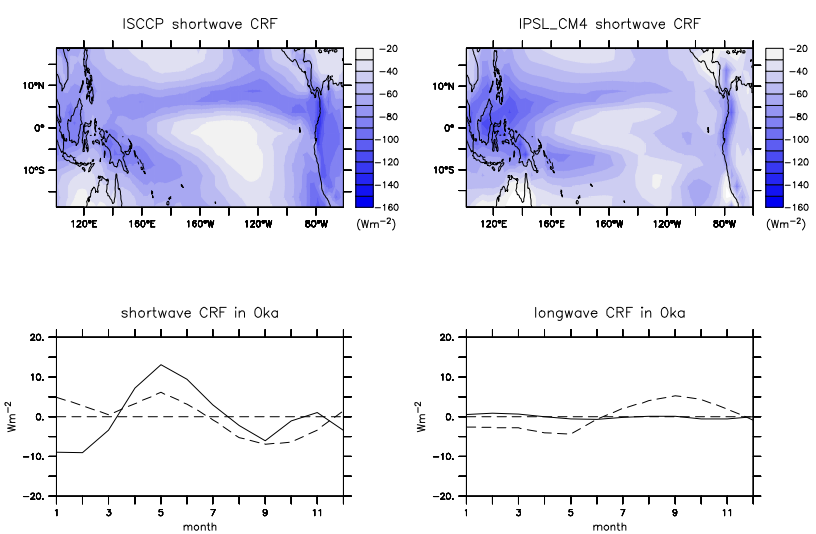

Fig. 5. Annual mean shortwave $\mathrm{CRF}\left(\mathrm{W} \mathrm{m}^{-2}\right)$ for the observed ISCCP data from 1984 to 1999 and IPSL_CM4 PI simulation (upper); Seasonal cycle of the shortwave and longwave CRF $\left(\mathrm{W} \mathrm{m}^{-2}\right.$, annual mean removed) at the surface in PI simulation for the western Pacific $\left(140^{\circ} \mathrm{E}-180^{\circ} \mathrm{E}, 5^{\circ} \mathrm{S}-5^{\circ} \mathrm{N}\right)$ (solid line) and the eastern $\mathrm{Pa}-$ cific $\left(90^{\circ} \mathrm{W}-150^{\circ} \mathrm{W}, 5^{\circ} \mathrm{S}-5^{\circ} \mathrm{N}\right)$ (dash line) (lower).

feedbacks play an important role. The maximum amplitude of the net surface heat flux is larger in the western tropical Pacific than in the eastern tropical Pacific. It results from the phase relationship between the PI cloud forcing and the insolation changes, with maximum and minimum cloud effect corresponding to decreased and increased insolation forcing at $9.5 \mathrm{ka}$ or $6 \mathrm{ka}$ (Figs. 4 and 5). Even though the differences with the pre-industrial values of the surface heat fluxes are similar for the mid and early Holocene, the magnitude is smaller for the mid-Holocene and, following the insolation forcing, minimum and maximum changes occurs in spring and late summer. The differences between the two periods reach up to about $10 \mathrm{~W} \mathrm{~m}^{-2}$ (Fig. $4 \mathrm{c}$ ).

\subsection{Mean climate's response to orbital forcing}

Figure 6 shows the simulated changes in annual mean SST, heat content and wind stress averaged from $5^{\circ} \mathrm{S}$ to $5^{\circ} \mathrm{N}$. The annual mean SST decreases in early and mid-Holocene along the equator and is characterized by a "U" shape across the basin, with lower annual mean SST decrease on both side of the basin and a larger decrease from $160^{\circ} \mathrm{E}$ to $120^{\circ} \mathrm{W}$ (Fig. 6a). Interestingly, the annual mean change in ocean heat content averaged over the upper $300 \mathrm{~m}$ depth has a very different structure, with increased heat content in the west from $130^{\circ} \mathrm{E}$ to $180^{\circ} \mathrm{E}$ and decreased heat content in the eastern tropical Pacific (Fig. 6b). Compared to early Holocene, the annual mean SST and heat content changes are smaller in mid-Holocene, which is consistent with the insolation forcing. The annual mean zonal SST cooling during the midHolocene is similar to the results of Brown et al. (2008a) using the HadCM3 model, in which it was attributed to the reduced annual mean insolation over the tropics. Figure $6 \mathrm{c}$ shows that in the $\mathrm{EH}$ and $\mathrm{MH}$ simulations the easterly trade 

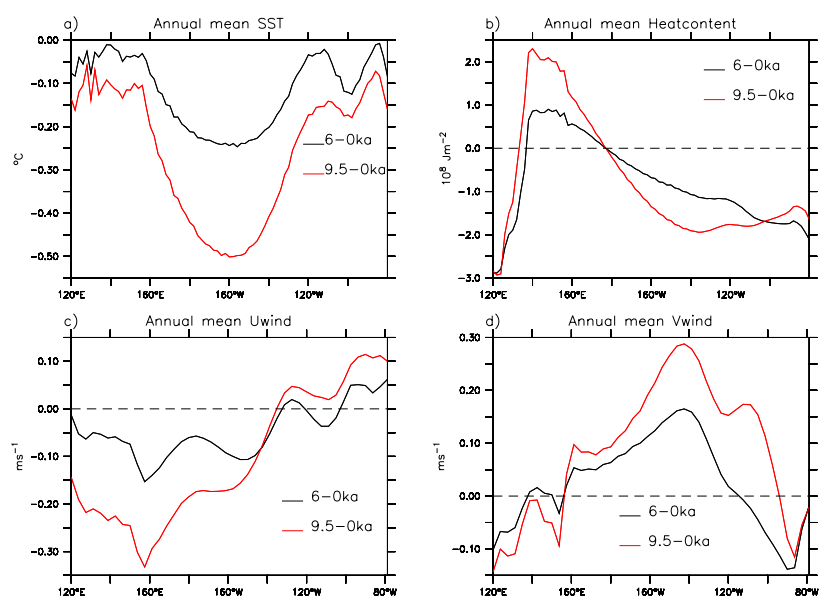

Fig. 6. Changes in annual mean (a) SST $\left({ }^{\circ} \mathrm{C}\right)$, (b) heat content $\left(10^{8} \mathrm{~J} \mathrm{~m}^{-2}\right)$, (c) surface zonal wind $\left(\mathrm{m} \mathrm{s}^{-1}\right)$ and (d) surface meridional wind $\left(\mathrm{m} \mathrm{s}^{-1}\right)$ along the equator (averaged between $5^{\circ} \mathrm{S}$ and $5^{\circ} \mathrm{N}$ ) between 6 and $0 \mathrm{kaBP}$ (black line) and 9.5 and $0 \mathrm{kaBP}$ (red line).

winds become stronger in the western and central tropical Pacific, which is consistent with the "U" shape in SST changes and increased heat content in the western Pacific. Changes in mean wind is stronger at $9.5 \mathrm{ka}$ with an increase in zonal wind twice as big as that at $6 \mathrm{ka}$ west of $160^{\circ} \mathrm{W}$ and changes in meridional wind twice as big as that at $6 \mathrm{ka}$ east of $160^{\circ} \mathrm{W}$ (Fig. 6c, d). As discussed in the introduction, the mean changes in SST in the equatorial Pacific and associated changes in precipitation are not strongly constrained by the available mid-Holocene proxy records. Our results further suggest that the La Niña-like mean SST response discussed in some papers (e.g. Bush, 2007) is not identified from the SST, but from the changes in the mixed layer characteristics, which may explain some of the mismatches between the previous studies (Sandweiss et al., 1996; Gagan et al., 1998; Tudhope et al., 2001; Stott et al., 2004).

The simulated changes in the SST seasonal cycle (annual mean removed) along the equator are shown in Fig. 7. In the Early Holocene, SST is cooler in winter and warmer in summer in the tropical Pacific, which is consistent with the changes in insolation. In the eastern tropical Pacific, the maximum SST changes occur in August with about one month delay compared to the maximum insolation changes (Fig. 3c). The model simulates larger SST anomalies in the eastern Pacific compared with the western Pacific despite being forced by a zonally uniform insolation change, reflecting the role of dynamical atmosphere-ocean coupling in controlling SSTs in this region. SST differences propagate from the eastern tropical Pacific to the western tropical Pacific. The maximum of SST anomalies has one month lag in the western Pacific (Fig. 7a), consistent with the differences in heat fluxes discussed above. Note also that the insolation forcing reinforces the seasonal cycle of SST in the west Pacific
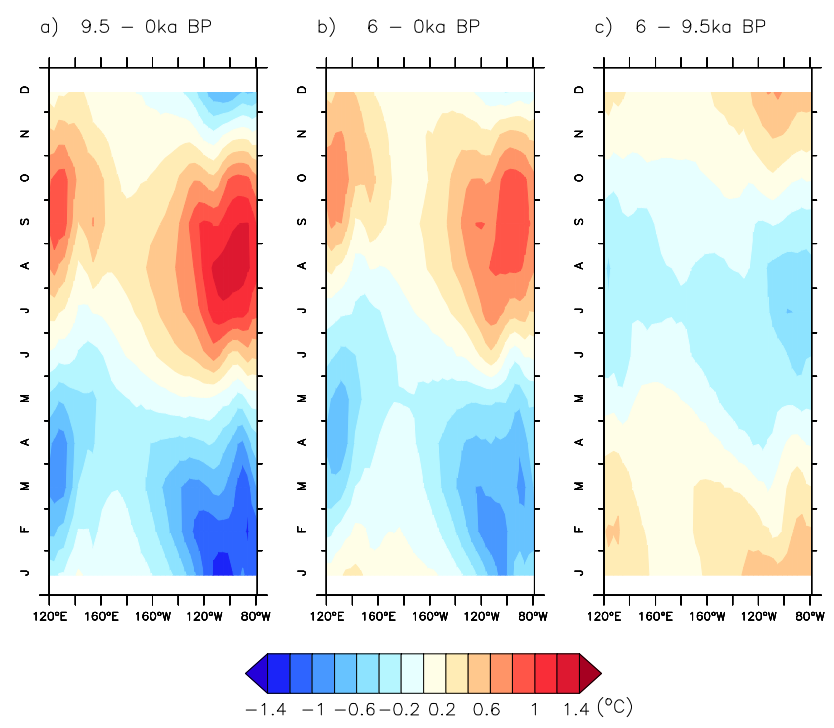

Fig. 7. Simulated changes in the SST $\left({ }^{\circ} \mathrm{C}\right)$ seasonal cycle (annual mean removed) averaged from $5^{\circ} \mathrm{S}$ to $5^{\circ} \mathrm{N}$ in the tropical Pacific for (a) 9.5-0 ka, (b) 6-0 ka, (c) 6-9.5 ka.

and damps it in the east. The MH simulation exhibits similar changes (Fig. 7b). However, SST in mid-Holocene is colder in summer and warmer in winter than SST in early Holocene (Fig. 7c).

Differences between SST and heat content changes are also found in the seasonal evolution of the SST and $300 \mathrm{~m}$ heat content gradients across the Pacific (Fig. 8). This gradient is computed using the average over two boxes located on the western part $\left(140^{\circ} \mathrm{E}-180^{\circ} \mathrm{E}, 5^{\circ} \mathrm{S}-5^{\circ} \mathrm{N}\right)$ and the eastern part $\left(150^{\circ} \mathrm{W}-90^{\circ} \mathrm{W}, 5^{\circ} \mathrm{S}-5^{\circ} \mathrm{N}\right)$ of the Pacific Ocean, respectively. It is positive all year long which corresponds to the mean difference between the west where the thermocline is deep and the east Pacific where the thermocline is shallow. In the PI simulation the SST gradient increases during the development phase of the upwelling in boreal summer and autumn, whereas the heat content gradient is larger in boreal spring (Fig. 8). Compared to the PI simulation, the increased SST gradient in the EH simulation is slightly reduced from May to October due to the warming in the eastern Pacific and the decreased SST gradient has a strong decline in winter due to the cooling (Fig. 8a). Changes of the whole heat content above $300 \mathrm{~m}$ in the ocean are consistent with the SST changes. However, the weakened heat content gradient occurs about one month earlier and dismisses about two months earlier in the EH simulation (Fig. 8b), indicating that subsurface temperature is warming or cooling earlier than the surface temperature. The annual mean evolution of this gradient is similar in $\mathrm{EH}$ and $\mathrm{MH}$ simulations, despite the shift in the insolation forcing. It has comparable magnitude with present day conditions for SST and is larger for heat content.

Compared to the PI simulation, the larger changes in the four seasons are found in the eastern Pacific where dynamical 

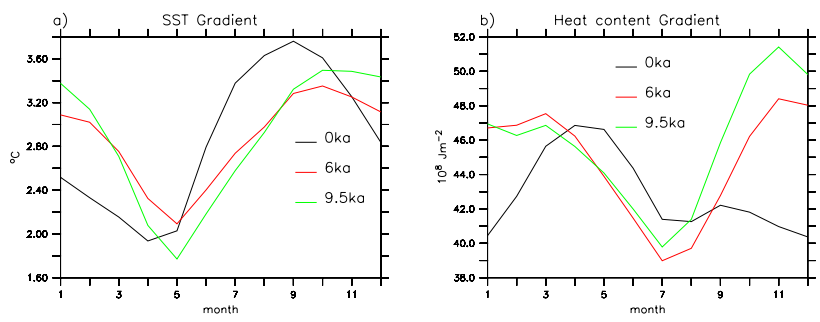

Fig. 8. Seasonal evolution of (a) $\operatorname{SST}\left({ }^{\circ} \mathrm{C}\right)$ and (b) $300 \mathrm{~m}$ heat content $\left(10^{8} \mathrm{~J} \mathrm{~m}^{-2}\right)$ gradients, computed as the different values of the averaged western Pacific $\left(140^{\circ} \mathrm{E}-180^{\circ} \mathrm{E}, 5^{\circ} \mathrm{S}-5^{\circ} \mathrm{N}\right)$ and the averaged eastern Pacific $\left(150^{\circ} \mathrm{W}-90^{\circ} \mathrm{W}, 5^{\circ} \mathrm{S}-5^{\circ} \mathrm{N}\right)$ for the different simulations.

processes strengthen the SST response (Braconnot et al., 2012) during the early and mid-Holocene. In boreal winter (DJF), greater cooling in the eastern Pacific and warming confined to the western Pacific are associated with easterly wind stress anomalies in the western and central equatorial Pacific and anticyclone wind stress anomalies outside the tropics. Meanwhile, precipitation is reduced in the tropical Pacific. Precipitation associated with the SPCZ is also intensified and shifted southward (Fig. 9). The easterly wind stress anomalies reinforce the thermocline tilt in the tropical ocean (Fig. 10). The positive subsurface temperature anomaly associated with the deepened thermocline in the western Pacific propagates along the thermocline to the central tropical Pacific in spring (MAM). However, cold SST anomalies are found at the surface throughout the basin. During boreal summer (JJA), the positive subsurface temperature anomaly reaches the east tropical Pacific and causes the thermocline to deepen. At the same time, increased insolation causes surface warming, and in turn leads to positive SST anomalies at the surface. In the eastern tropical Pacific, convergent wind stress anomalies (Fig. 9) in response to the positive SST anomalies damp the upwelling. All these processes induce warmer SST in the eastern Pacific than in the western Pacific. Meanwhile, negative subsurface temperature anomalies occur in the western tropical Pacific. The wind induced dynamical changes and propagation of the signal at the depth of the thermocline explains that the maximum changes in temperature are found at the subsurface and not at the surface (Fig. 10). Precipitation is increased in JJA in the eastern tropical Pacific. In boreal autumn (SON), the cooling subsurface temperature propagates from the western tropical Pacific enhances the upwelling in the eastern tropical Pacific (Fig. 11) and results in a modest weakening of the equatorial thermocline depth from September.

\subsection{Interannual variability characteristics}

The insolation forcing together with the changes in the mean state also have an impact on the characteristics of the interannual variability. As discussed in Braconnot et al. (2012),
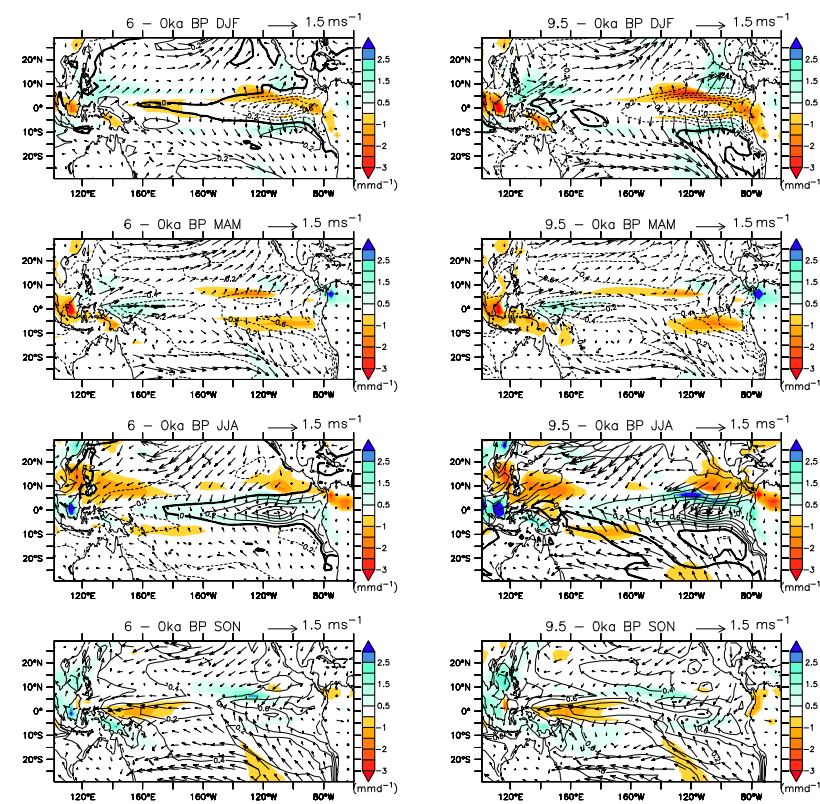

Fig. 9. Changes in simulated SST (line, ${ }^{\circ} \mathrm{C}$ ), precipitation (color, $\mathrm{mm} \mathrm{d}^{-1}$ ) and wind stress anomalies (arrow, $\mathrm{ms}^{-1}$ ) for the midHolocene (6-0 ka, left) and the early Holocene (9.5-0 ka, right) in the four seasons (DJF, MAM, JJA, SON).

the magnitude of El Niño and La Niña events is damped. The larger differences were found for the EH simulation in the Niño3 box. The differences appear to be statistically significant in the east during the development phase of the events. This was attributed to the enhanced convergence of wind onto the Indian and Southeast Asian monsoon in the west Pacific, as well as the strengthening of the easterly trade wind in the middle of the tropical Pacific.

Braconnot et al. (2012) only present the evolution of the El Niño and La Niña composite considering the Niño3 box. Here we go one step further and show in Fig. 12 the El Niño composite for SST, precipitation and wind stress anomalies in EH and $\mathrm{MH}$ simulations over the tropical Pacific to better highlight the patterns, and regional differences with the PI simulation. Figure 13 shows the difference in SST and highlights the regions where they are significant from student T-tests using the dispersion between the different events to compute the confidence interval. The characteristics of the El Niño events in early and mid-Holocene resemble those of the PI simulation described in Sect. 3.2. Some differences, such as the one month delay, can be found in the central part of the basin and at the Peru and Chile coast (Fig. 12). In the EH simulation, the positive SST anomalies starts in June in the eastern Pacific, and is accompanied by westerly wind stress anomalies in the western tropical Pacific and positive precipitation anomalies in the eastern tropical Pacific (Fig. 12). Figure 13 highlights that the magnitude of the El Niño is significantly damped in the middle of the basin in August and then this damping propagates to the east and to 

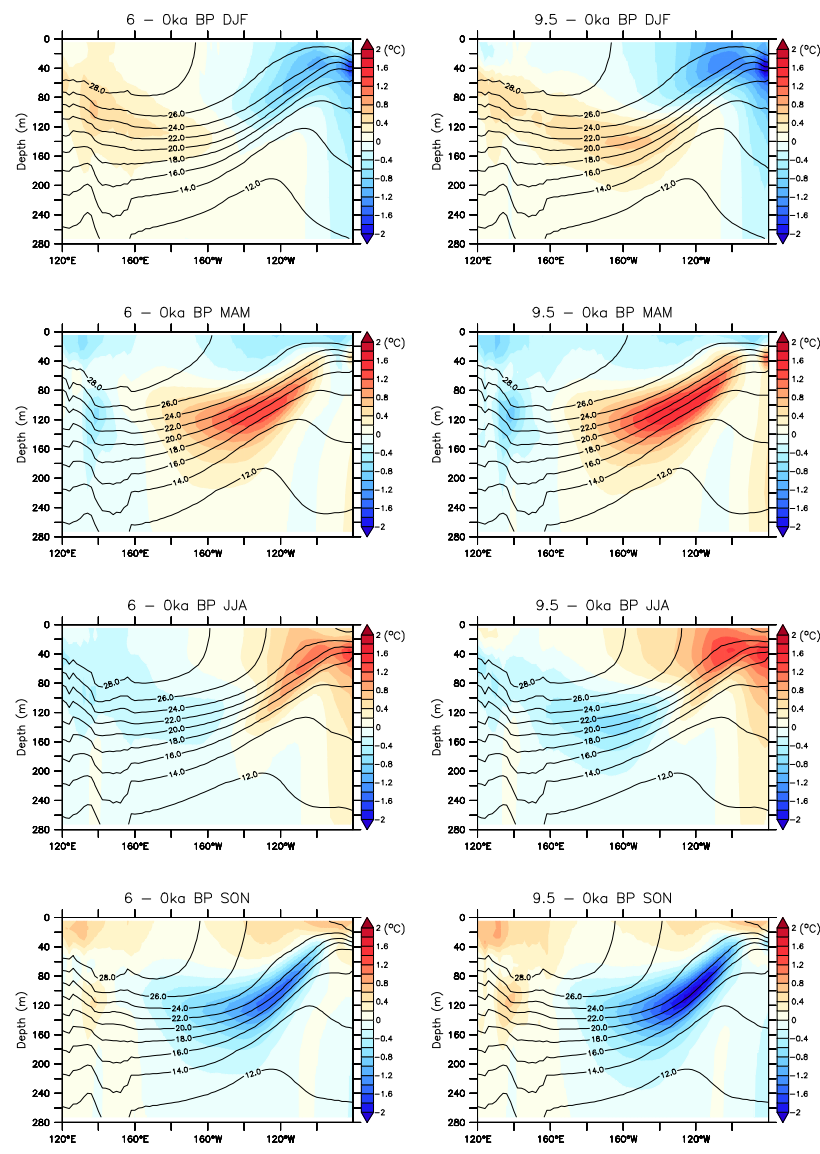

Fig. 10. Changes of the subsurface ocean temperature (color, ${ }^{\circ} \mathrm{C}$ ) along the equator for the mid-Holocene (6-0 ka, left) and the early Holocene (9.5-0 ka, right) in the four seasons (DJF, MAM, JJA, $\mathrm{SON})$. The equatorial sections are averaged over the $5^{\circ} \mathrm{S}$ and $5^{\circ} \mathrm{N}$ latitude band. Contour line is subsurface ocean temperature in the PI simulation.

the west in subsequent months. In the western part, SSTs are warmer than in the PI simulations. Significant differences are also found in the off-equator regions, such as in the southwestern tropical Pacific. The horseshoe shape of these differences reflects an overall damping of the El Niño development across the basin. Along the equator, the mean state prevents the propagation of the downwelling Kelvin wave during the development phase of the event. Indeed, during that period, both the east-west temperature and heat content gradients are already relaxed compared to the pre-industrial conditions (Fig. 8). Two effects therefore counteract the developments of the anomalies, the propagation of a downwelling wave along the thermocline in the mean state and the upwelling of warmer water than in the PI simulation in the east limit the surface warming. Then at the peak of the event the propagation of the upwelling wave and the strengthening of the east-west temperature and heat content gradients in response to the mean wind further damp the intensity of the event, and contribute to delaying its termination by about one month

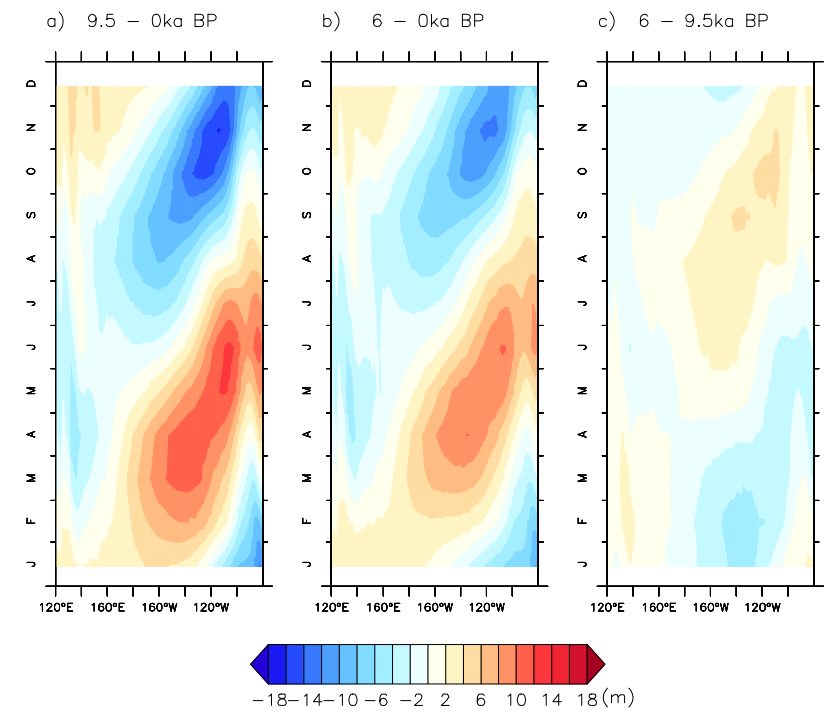

Fig. 11. Seasonal cycle of the thermocline depth as defined by the $20^{\circ} \mathrm{C}$ isotherm depth $(\mathrm{m})$ average between $5^{\circ} \mathrm{S}$ and $5^{\circ} \mathrm{N}$ for (a) $9.5-0 \mathrm{ka}$, (b) 6-0 ka, (c) 6-9.5 ka.

(Fig. 12). Figure 13 clearly shows that the largest differences with PI simulation occur along the east coast and in the middle of the basin. The event also produces warm anomalies further west compared to PI simulation.

The MH simulation also produces decreased El Niño amplitude compared to PI simulation. But compared to the EH simulation, the MH SST anomalies have a smaller magnitude during the El Niño onset (May-June) along the equator. The peak El Niño amplitude is thus larger in the eastern Pacific (Fig. 13), suggesting that El Niño was existed throughout the Holocene but underwent a steady increase in amplitude from the early Holocene to mid-Holocene, and then to the present day. One of the possible reasons is that insolation seasonality is larger in EH (Fig. 3c) and the EH receives more surface heat flux in summer (Fig. 4c), inducing larger changes in the magnitude of the SST and heat content gradients. The major differences with EH simulation occurs along the coast and propagate westward. This suggests that the Chile and Peru coastal regions are the regions where the larger changes may have been recorded between the early and mid-Holocene. Substantial differences are also found in the southwest Pacific. As noted in Sect. 4.3, the changes in SST and heat content gradients are in phase for $\mathrm{EH}$ and $\mathrm{MH}$ despite the one month delay insolation between the two periods. This explains why the timing of the El Niño events are similar for the two periods.

Figure 14 presents similar diagnoses for composite La Niña years. The EH and MH simulations produce a decrease in La Niña amplitude compared to PI simulation and the differences are significant. However, La Niña amplitude has a slight increase in the early Holocene compared to the midHolocene but without statistical significant. This reduction is 

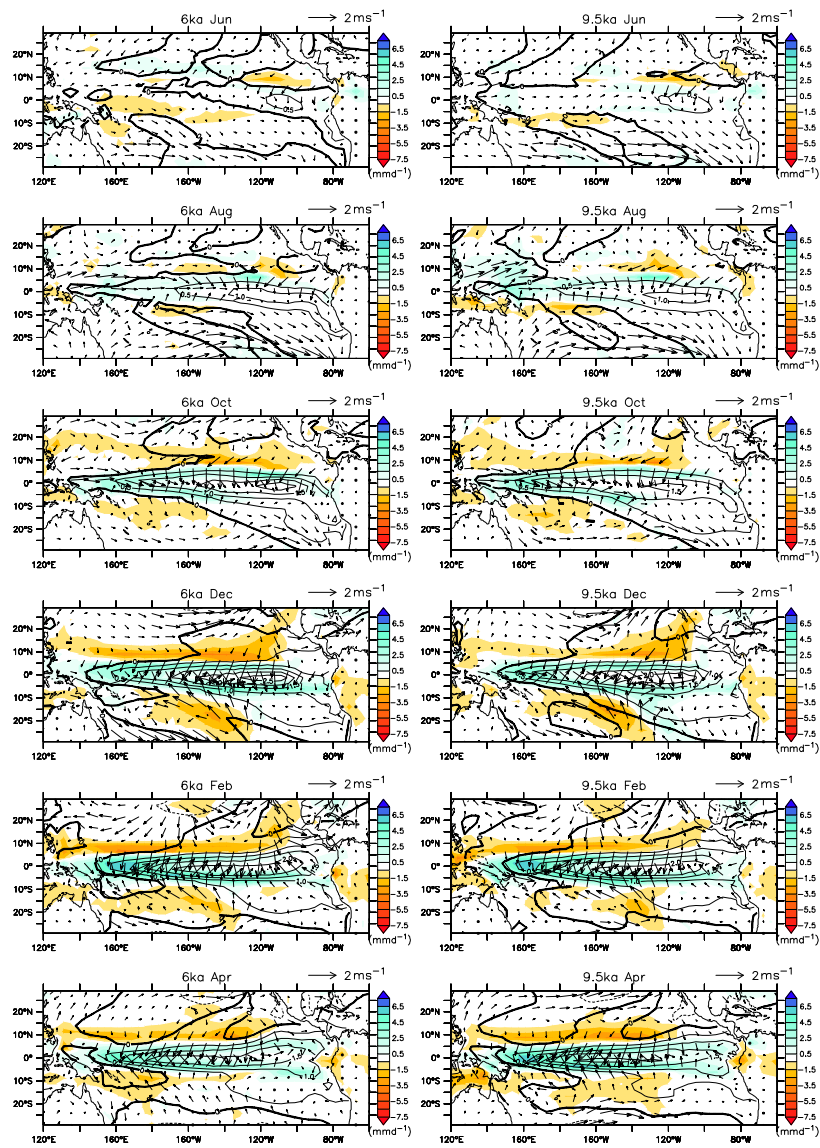

Fig. 12. Time evolution of SST (line, ${ }^{\circ} \mathrm{C}$ ), precipitation (color, $\mathrm{mm} \mathrm{d}^{-1}$ ) and wind stress anomalies (arrow, $\mathrm{m} \mathrm{s}^{-1}$ ) during the composite El Niño year minus mean state in the $6 \mathrm{ka}$ (left) and $9.5 \mathrm{ka}$ (right) simulations.

also linked to the mean state. The intensification of the mean state during a La Niña year is associated to the westward advection of warmer water than PI simulation along the equator, resulting from the damping of the equatorial upwelling, thereby limiting the cooling effect compared to PI simulation. As for the El Niño events, significant differences are found along the coast of Chile and in the southwest Pacific for the La Niña events.

\section{The role of the Obliquity}

The insolation forcing considered in the MH and EH simulation results both from changes in precession and in obliquity. Precession controls the seasonal variations of insolation whereas obliquity controls the contrast between low and high latitudes. A reduction in obliquity increases the meridional gradient of the annual mean insolation but weakens the magnitude of the seasonal cycle in both hemispheres. During the Early Holocene period, the obliquity $(\varepsilon=24.231)$ was larger than that in present day $(\varepsilon=23.446)$ (Berger, 1978; Marzin
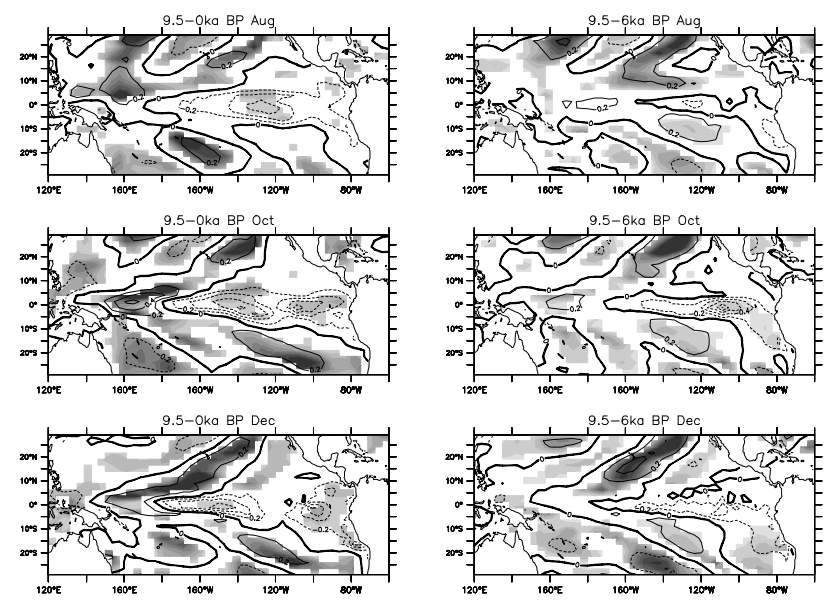

Fig. 13. Changes in simulated SST (line, ${ }^{\circ} \mathrm{C}$ ) during composite El Niño year for 9.5-0 ka (left) and 9.5-6 ka (right). Shading indicates significant SST differences at $95 \%(9.5-0 \mathrm{ka})$ and $80 \%(9.5-6 \mathrm{ka})$ confidence level using t-test.
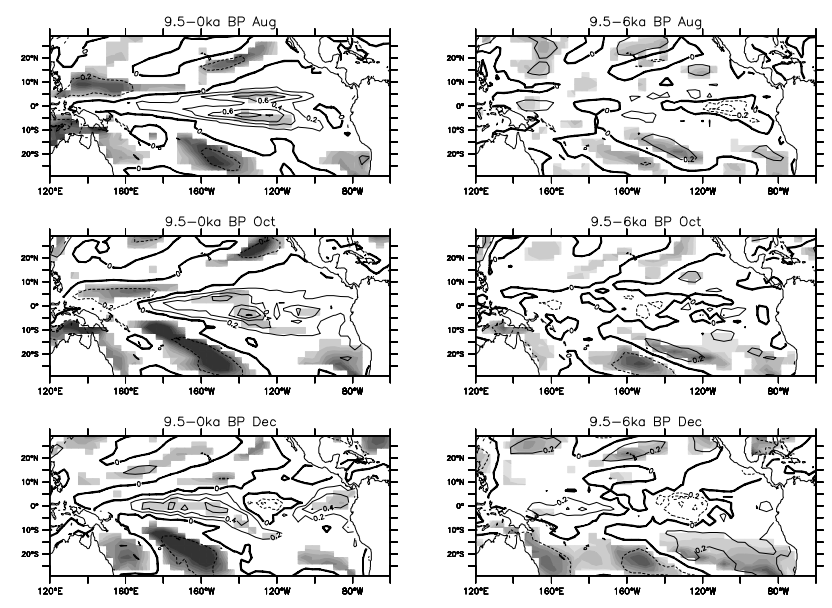

Fig. 14. Same as Fig. 13, but during composite La Niña year.

and Braconnot, 2009). Clement et al. (2004) shows the importance of precessional signals in past variations of the tropical climate using an atmospheric general circulation model coupled to a slab ocean model. However, they did not consider the interannual variability in the tropical Pacific because of the absence of fully interactive ocean dynamics. In order to discuss the roles of the precession and obliquity in affecting the tropical climate respectively, we further study the impact of obliquity on the characteristics of the seasonal cycle and ENSO.

The increase in the obliquity from 23.446 to 24.231 slightly reduces the annual mean insolation at the equator by $1.0 \mathrm{~W} \mathrm{~m}^{-2}$. However, it causes a larger increase by $5.0 \mathrm{~W} \mathrm{~m}^{-2}$ in middle and high latitudes. This is due to the in-phase relationship between annual solar irradiation and obliquity in high latitudes and anti-phase between them in 

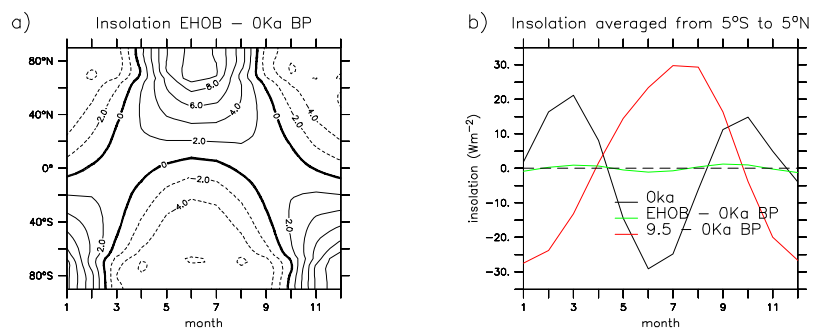

Fig. 15. Difference in insolation distribution as a function of time and latitude between EHOB and $0 \mathrm{ka} \mathrm{BP}(\mathbf{a})$ and Insolation averaged from $5^{\circ} \mathrm{S}$ to $5^{\circ} \mathrm{N}$ and plotted as a function of months for $0 \mathrm{ka}$ (black line), EHOB-0 ka BP (green line) and 9.5-0 ka BP (red line) (b).
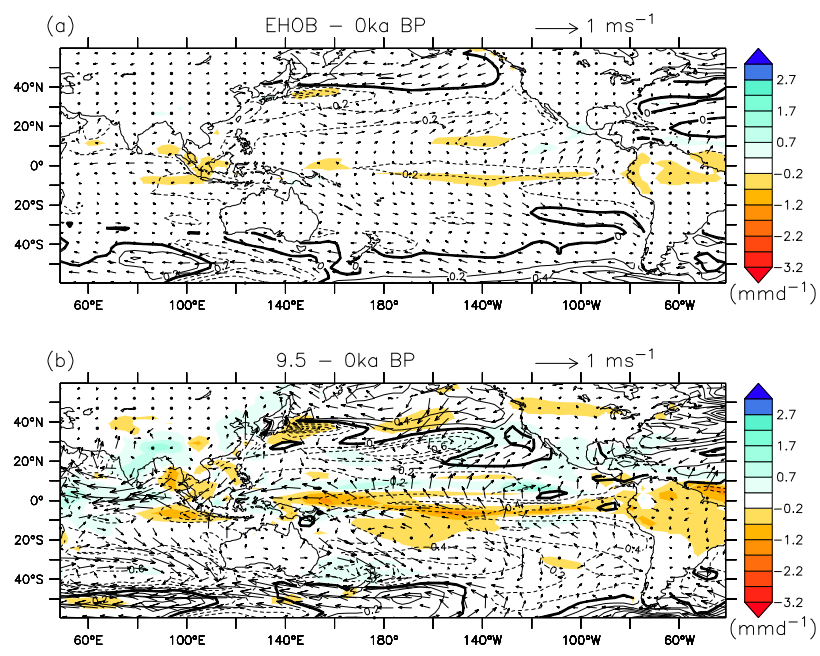

Fig. 16. Differences of annual mean SST (line, ${ }^{\circ} \mathrm{C}$ ), precipitation (color, $\mathrm{mm} \mathrm{d}^{-1}$ ) and wind stress anomalies (arrow, $\mathrm{m} \mathrm{s}^{-1}$ ) over the Pacific and Indian Oceans for (a) EHOB-0 ka BP, (b) 9.5-0 ka BP.

low latitudes (Berger et al., 2010). The orbital forcing also intensifies the seasonal contrast at each latitude, because of an increase of the summer hemisphere insolation and a reduction of the winter hemisphere insolation (Fig. 15a). However, in the equatorial Pacific, the seasonal cycle of the insolation is only intensified by $1.0 \mathrm{~W} \mathrm{~m}^{-2}$ in the EHOB simulation. Note that the obliquity slightly enhances the seasonal cycle but does not modulate its seasonal timing. The modulation of the timing and shape of the seasonal cycle in EH is induced by the precession changes (Fig. 15b).

Mantsis et al. (2011) discussed the effect of a reduction in obliquity showing that it generally increases the surface temperature at low latitudes and decreases it at high latitudes. The direct obliquity forcing is mainly balanced by the poleward heat transport. They also showed that the changes of temperature in the subtropics and parts of the tropics are affected by the strong influence of feedbacks; in which, clouds and the lapse rate have the larger contribution. Our simulations confirm these results. The coupled system responds
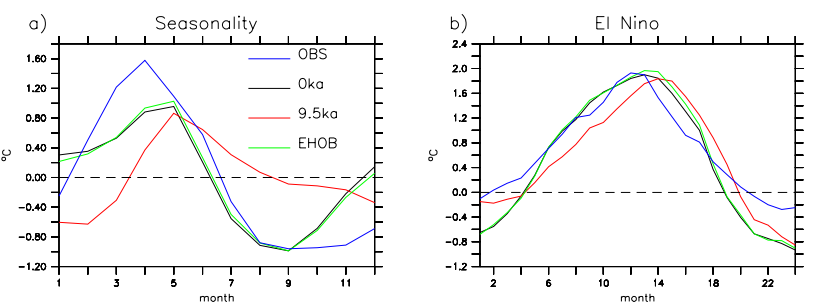

Fig. 17. Evolution of SST $\left({ }^{\circ} \mathrm{C}\right)$ for (a) seasonality and (b) composites of El Niño events in Niño3 box for the different simulations.

to the change in obliquity by a slight strengthening of the ocean and atmospheric circulation and increases the poleward transport. Liu et al. (2003) further indicates that the annual mean tropical cooling during Holocene mainly results from the annual mean insolation forcing. The comparison of the simulated annual mean changes in SST (Fig. 16) show that this holds in our study and contributes to the about $0.2{ }^{\circ} \mathrm{C}$ tropical cooling simulate in both simulations. Note however that regional changes are larger at $9.5 \mathrm{ka}$ due to changes in upwelling intensity induced by precession.

Annual mean tropical cooling and the changes in the meridional SST gradient have a slight impact on the location of the ITCZ. Figure 16a suggests that annual mean tropical cooling induces a reduction in annual mean precipitation around $5^{\circ} \mathrm{S}$ and an increase between the equator and $5^{\circ} \mathrm{N}$ across Panama, those are reinforced with precession. South America and the Indonesian sector are more sensitive, even though the signal is small. At the seasonal time scale (not shown), several patterns in SST and precipitation look quite similar between the $9.5 \mathrm{ka}$ and EHOB simulation, suggesting that the seasonal march of the ITCZ in South America and in Asia is strongly linked to the meridional temperature gradients. However, our results confirm that the magnitudes of the changes are driven by precession in all regions.

The changes in the mean state are not sufficient to alter ENSO characteristics in EHOB compared to EH (Fig. 17). Indeed in Niño3 area, the SST seasonality in the eastern Pacific is very similar to that in the PI simulation. The amplitude of El Niño does not change compared to the PI simulation too. The precession is more important than obliquity in affecting the tropical Pacific SST seasonality and interannual variability. This reinforces the hypothesis that changes in the seasonality of the mean background climate state is the major driver of ENSO changes during the mid-Holocene, and that the strengthening of the wind stress across the equator Pacific in summer has a major control on the development of ENSO. 


\section{Conclusions}

Using a coupled ocean-atmosphere general circulation model IPSL_CM4, this study presents how the orbital forcing affects the tropical Pacific SST seasonality and interannual variability behavior. The simulations for the $0,6,9.5 \mathrm{kaBP}$ climates are compared. They only account for the differences in orbital configuration. The changes in SST seasonality between the western and the eastern Pacific and the reduction of interannual variability are discussed in Braconnot et al. (2012). They are consistent with proxy reconstructions (Rodbell et al., 1999; Moy et al., 2002). We provide here additional analyses of the key aspects of the forcing and climate response that allow to (1) understand the characteristics of ENSO in the early to mid-Holocene compared to modern conditions or (2) to understand the differences and similarities between the $\mathrm{EH}$ and the $\mathrm{MH}$. In particular we consider an additional simulation for which only the obliquity is prescribed to its EH value and show that the obliquity change has little effect on SST seasonal cycle, and interannual variability in eastern tropical Pacific in our analysis. The precession of the equinoxes is more important in affecting the tropical climate. However, the obliquity change affects the seasonal displacement of ITCZ related to strengthening of SST meridional gradients.

The detail analysis indicates that the annual mean SST decreases along the whole equator (Brown et al., 2008a). The striking feature is that the annual mean SST is characterized by a "U" shape across the basin, which is induced by the stronger easterly trade winds in the western and middle equatorial Pacific. The annual mean changes in ocean heat content above the upper $300 \mathrm{~m}$ show a very different structure, with increased heat content in the west from $130^{\circ} \mathrm{E}$ to $180^{\circ} \mathrm{E}$ and decreased heat content in the east tropical Pacific due to enhanced easterly winds. The model simulates larger SST anomalies in the eastern Pacific than in the western Pacific despite being forced by a zonally uniform insolation change, indicating the strong influence of feedbacks.

Thermodynamic and dynamic feedbacks intensify the SST anomalies caused by the insolation changes. The insolation forcing and the cloud radiative forcing mainly affect the surface heat fluxes changes. The seasonal changes of the EH or MH insolation forcing is in (out of) phase with the seasonal evolution of SST in the west (east) Pacific, strengthening seasonality in the west and damping it in the east. In the PI simulation, the net CRF largely reduces the shortwave radiation in the western tropical Pacific in winter, converting the zonally uniform solar forcing into a zonally asymmetric response. The effect of clouds also induces an asymmetry in the solar forcing and reinforces the east-west differences. In the tropical eastern Pacific, because of the southward shift of the ITCZ in the region of the Panama isthmus, the northward component of the wind stress across the equator is weakened, which dampens the equatorial upwelling (Braconnot et al., 2012). These changes are linked to the changes in wind convergence over the North American monsoon region which originates from the subtropical North Pacific and not from a strengthening of cross equatorial wind. Similar upwelling reductions are found in the Gulf of Guinea (Marzin and Braconnot, 2009). It also stresses that cross equatorial winds are as important as zonal wind to trigger the equatorial upwelling at the coast (Braconnot et al., 2007b; Xie et al., 2008).

Several factors contributing to the reduction in ENSO amplitude are highlighted (Table 1). Here we show that the relative timing of the changes in seasonality and of the development of El Niño or La Niña events is a key factor in the development of the events. The orbital forcing enhances heat contrast between two hemispheres as well as the land and the sea, which results in strengthening the southeasterly trade winds and the south Asian monsoon flow (Marzin and Braconnot, 2009). The stronger Asian monsoon finally enhances the easterly trade winds through the atmospheric Walker Circulation in boreal summer. Both factors damp the development of warm events. The amplitude of ENSO may be also influenced by changes in the depth and intensity of the thermocline (Meehl et al., 2001). However, Wanner et al. (2008) suggested that as a consequence of a changing SST gradient between the Indo-Pacific warm pool and the eastern Pacific Ocean, the Walker Circulation intensified in mid-Holocene and strong El Niño events occurred more frequently. In our analysis, the reduction of ENSO amplitude is affected by the mean seasonality of the mean state. In the beginning of the El Niño development, an uplift of the equatorial Pacific thermocline in the eastern equatorial Pacific is seen in the EH and MH simulations. This counteracts the development of the ElNiño anomalous downwelling Kelvin wave. The thermocline tilt is controlled by the cross equatorial strengthening of the trade winds and the intensification Asian summer monsoon in the extra-tropics. Meanwhile both the SST and heat content east-west gradients are relaxed compared to PI simulation and further dampen the development of the events. That is also the reason why the timing of the El Niño event is similar for the two periods, even though there are differences in timing in insolation between $\mathrm{EH}$ and $\mathrm{MH}$.

These results also show that SST anomalies have a complex structure that reflects both dynamical and thermodynamical forcing. Temperature changes are large at the thermocline depth and better reflect the changes in the wind stress forcing. Following the discussion of DiNezio et al. (2011) for the last glacial maximum, it strongly suggests that subsurface proxy records would provide a better constraint than SST proxies on the mean ocean state. Also multiproxy integrations considering both changes in the mean state and in variability would be of great use to assess the realism of climate model and to better understand the link between seasonality and interannual variability, thus helping to improve climate predictability. 
Acknowledgements. The NEC SX8 computing time requested to run the simulations has been provided by CEA (France). This study contributes to the French ANR Project ELPASO (no. 2010 BLANC 608 01), the European project Past4Future and is jointly supported by the "Strategic Priority Research Program - Climate Change: Carbon Budget and Related Issues" of the Chinese Academy of Sciences (no. XDA01020304) and China NSFC grant (no. 40975065). Yihua Luan received a PhD grant from the French Embassy in Beijing.

Edited by: M.-F. Loutre

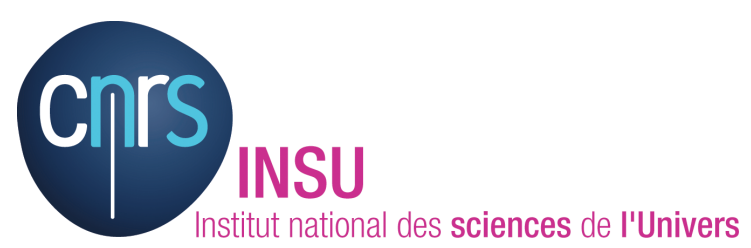

The publication of this article is financed by CNRS-INSU.

\section{References}

AchutaRao, K. and Sperber, K. R.: ENSO simulation in coupled ocean-atmosphere models: are the current models better?, Clim. Dynam., 27, 1-15, 2006.

Annamalai, H., Hamilton, K., and Sperber, K. R.: The South Asian Summer Monsoon and Its Relationship with ENSO in the IPCC AR4 Simulations, J. Climate, 20, 1071-1092, 2007.

Berger, A. L.: Long-term variations of daily insolation and quaternary climatic changes, J. Atmos. Sci., 35, 2362-2367, 1978.

Berger, A. L., Loutre, M. F., and Yin, Q. Z.: Total irradiation during any time interval of the year using elliptic integrals, Quaternary Sci. Rev., 29, 1968-1982, 2010.

Braconnot, P., Hourdin, F., Bony, S., Dufresne, J. L., Grandpeix, J. Y., and Marti, O.: Impact of different convective cloud schemes on the simulation of the tropical seasonal cycle in a coupled ocean-atmosphere model, Clim. Dynam., 29, 501-520, 2007a.

Braconnot, P., Otto-Bliesner, B., Harrison, S., Joussaume, S., Peterchmitt, J.-Y., Abe-Ouchi, A., Crucifix, M., Driesschaert, E., Fichefet, Th., Hewitt, C. D., Kageyama, M., Kitoh, A., Laîné, A., Loutre, M.-F., Marti, O., Merkel, U., Ramstein, G., Valdes, P., Weber, S. L., Yu, Y., and Zhao, Y.: Results of PMIP2 coupled simulations of the Mid-Holocene and Last Glacial Maximum Part 1: experiments and large-scale features, Clim. Past, 3, 261277, doi:10.5194/cp-3-261-2007, 2007b.

Braconnot, P., Luan, Y., Brewer, S., and Zheng, W.: Impact of Earth's orbit and freshwater fluxes on Holocene climate mean seasonal cycle and ENSO characteristics, Clim. Dynam., 38, 1081-1092, doi:10.1007/s00382-011-1029-x, 2012.

Brown, J., Collins, M., and Tudhope, A.: Coupled model simulations of mid-Holocene ENSO and comparison with coral oxygen isotope records, Adv. Geosci., 6, 29-33, doi:10.5194/adgeo-629-2006, 2006.

Brown, J., Collins, M., Tudhope, A. W., and Toniazzo, T.: Modelling mid-Holocene tropical climate and ENSO variability: towards constraining predictions of future change with palaeodata, Clim. Dynam., 30, 19-36, 2008a.
Brown, J., Tudhope, A. W., Collins, M., and McGregor, H. V.: Mid-Holocene ENSO: Issues in quantitative modelproxy data comparisons, Paleoceanography, 23, PA3202, doi:10.1029/2007PA001512, 2008b.

Bush, A.: Assessing the impact of Mid-Holocene insolation on the atmosphere-ocean system, Geophys. Res. Lett., 26, 99-102, 1999.

Bush, A.: Extratropical influences on the El Niño-southern oscillation through the late quaternary, J. Climate, 20, 788-800, doi:10.1175/Jcli4048.1, 2007

Chiang, J. C. H., Fang, Y., and Chang, P.: Pacific climate change and ENSO activity in the mid-Holocene, J. Climate, 22, 923939, 2009.

Clement, A. C., Seager, R., Cane, M. A., and Zebiak, S. E.: An ocean dynamical thermostat, J. Climate, 9, 2190-2196, 1996.

Clement, A. C., Seager, R., and Cane, M. A.: Orbital controls on ENSO and tropical climate, Paleoceanography, 14, 441-456, 1999.

Clement, A. C., Seager, R., and Cane, M. A.: Suppression of El Niño during the mid-Holocene by changes in the Earth's orbit, Paleoceanography, 15, 731-737, 2000.

Clement, A. C., Cane, M. A., and Seager, R.: An orbitally driven tropical source for abrupt climate change, J. Climate, 14, 23692375, 2001.

Clement, A. C., Hall, A., and Broccoli, A. J.: The importance of precessional signals in the tropical climate, Clim. Dynam., 22, 327-341, 2004.

Collins, M.: El Niño- or La Niña-like climate change, Clim. Dynam., 24, 89-104, 2005.

Collins, M., Tett, S. F. B., and Cooper, C.: The internal climate variability of HadCM3, a version of the Hadley Centre coupled model without flux adjustments, Clim. Dynam., 17, 61-81, 2001.

Collins, M., An, S. I., Cai, W. J., Ganachaud, A., Guilyardi, E., Jin, F. F., Jochum, M., Lengaigne, M., Power, S., Timmermann, A., Vecchi, G., and Wittenberg, A.: The impact of global warming on the tropical Pacific ocean and El Niño, Nat. Geosci., 3, 391-397, doi:10.1038/Ngeo868, 2010.

DiNezio, P. N., Clement, A., Vecchi, G. A., Soden, B., Broccoli, A. J., Otto-Bliesner, B. L., and Braconnot, P.: The response of the Walker circulation to Last Glacial Maximum forcing: Implications for detection in proxies, Paleoceanography, 26, PA3217, doi:10.1029/2010PA002083, 2011.

Fichefet, T. and Maqueda, M. A. M.: Sensitivity of a global sea ice model to the treatment of ice thermodynamics and dynamics, J. Geophys. Res., 102, 12609-12646, 1997.

Gagan, M. K., Ayliffe, L. K., Hopley, D., Cali, J. A., Mortimer, G. E., Chappell, J., McCulloch, M. T., and Head, M. J.: Temperature and surface-ocean water balance of the mid-Holocene tropical western Pacific, Science, 29, 1014-1018, 1998.

Gordon, C. T. and Stern, W.: A description of the GFDL global Spectral model, Mon. Weather Rev., 110, 625-644, 1982.

Guilyardi, E.: El Niño-mean state-seasonal cycle interactions in a multi-model ensemble, Clim. Dynam., 26, 329-348, 2006.

Guilyardi, E., Braconnot, P., Jin, F. F., Kim, S. T., Kolasinski, M., Li, T., and Musat, I.: Atmosphere Feedbacks during ENSO in a Coupled GCM with a Modified Atmospheric Convection Scheme, J. Climate, 22, 5698-5718, 2009.

Hourdin, F., Musat, I., Bony, S., Braconnot, P., Codron, F., Dufresne, J. L., Fairhead, L., Filiberti, M. A., Friedlingstein, P., 
Grandpeix, J. Y., Krinner, G., Levan, P., Li, Z. X., and Lott, F.: The LMDZ4 general circulation model: climate performance and sensitivity to parametrized physics with emphasis on tropical convection, Clim. Dynam., 27, 787-813, 2006.

IPCC: Climate Change 2007, The Physical Science Basis - Summary for Policymakers, 21 pp., 2007.

Jacob, R.: Low frequency variability in a simulated atmosphere ocean system, Ph.D thesis, University of Wisconsin-Madison, 1997.

Joussaume, S. and Braconnot, P.: Sensitivity of paleoclimate simulation results to season definitions, J. Geophy. Res., 102, 19431956, 1997.

Kao, H.-Y. and Yu, J.-Y.: Contrasting eastern-Pacific and centralPacific types of ENSO, J. Climate, 22, 615-632, 2009.

Kiehl, J. T., Hack, J. J., Bonan, G. B., Boville, B. A., Williamson, D. L., and Rasch, P. J.: The National Center for Atmospheric Research Community Climate Model: CCM3, J. Climate, 11, 11311149, 1998.

Koutavas, A., Lynch-Stieglitz, J., Marchitto, T. M., and Sachs, J. P.: El Niño-like pattern in Ice Age tropical Pacific sea surface temperature, Science, 297, 226-230, 2002.

Krinner, G., Viovy, N., de Noblet-Ducoudre, N., Ogee, J., Polcher, J., Friedlingstein, P., Ciais, P., Sitch, S., and Prentice, I. C.: A dynamic global vegetation model for studies of the coupled atmosphere-biosphere system, Global Biogeochem. Cy., 19, GB1015, doi:10.1029/2003GB002199, 2005.

Kug, J.-S., Jin, F.-F., and An, S.: Two types of El Niño events: Cold tongue El Niño and warm pool El Niño, J. Climate, 22, 1499$1515,2009$.

Latif, M., Kleeman, R., and Eckert, C.: Greenhouse warming, decadal variability, or El Niño? An attempt to understand the anomalous 1990s, J. Climate, 10, 2221-2239, 1997.

Lau, N. C. and Nath, M. J.: Impact of ENSO on the Variability of the Asian-Australian Monsoons as Simulated in GCM Experiments, J. Climate, 13, 4287-4309, 2000.

Lea, D. W., Pak, D. K., Belanger, C. L., Spero, H. J., Hall, M. A., and Shackleton, N. J.: Paleoclimate history of Galapagos surface waters over the last 135,000 yr, Quaternary Sci. Rev., 25, 11521167, 2006.

Leloup, J., Lengaigne, M., and Boulanger, J. P.: Twentieth century ENSO characteristics in the IPCC database, Clim. Dynam., 30, 277-291, 2008.

Levitus, S.: Climatological atlas of the world ocean, EOS T. Am. Geophys. Un., 64, 1983, doi:10.1029/EO064i049p0096202, 1983.

Liu, Z., Jacobs, R., Kutzbach, J., Harrison, S., and Anderson, J.: Monsoon impact on El Niño variability in the early Holocene, PAGES Newsletter, 7, 16-17, 1999.

Liu, Z., Kutzbach, J., and Wu, L.: Modeling climate shift of El Niño variability in the Holocene, Geophys. Res. Lett., 27, 2265-2268, 2000.

Liu, Z., Otto-Bliesner, B., Kutzbach, J., Li, L., and Shields, C.: Coupled model simulation of the evolution of global monsoons in the Holocene, J. Climate, 16, 2472-2490, 2003.

Madec, G., Delecluse, P., Imbard, M., and Levy, C.: OPA version 8.1 ocean general circulation model reference manual, LODYC/IPSL, Paris, France, No. 11, 91 pp., 1998.

Mantsis, D. F., Clement, A. C., Broccoli, A. J., and Erb, M. P.: Climate feedbacks in response to changes in obliquity, J. Climate,
24, 2830-2845, 2011.

Marti, O., Braconnot, P., Dufresne, J.-L., Bellier, J., Benshila, R., Bony, S., Brockmann, P., Cadule, P., Caubel, A., Codron, F., de Noblet, N., Denvil, S., Fairhead, L., Fichefet, T., Foujols, M.A., Friedlingstein, P., Goosse, H., Grandpeix, J.-Y., Guilyardi, E., Hourdin, F., Idelkadi, A., Kageyama, M., Krinner, G., Levy, C., Madec, G., Mignot, J., Musat, I., Swingedouw, D., and Talandier, C.: Key features of the IPSL ocean atmosphere model and its sensitivity to atmospheric resolution, Clim. Dynam., 34, 1-26, 2010.

Marzin, C. and Braconnot, P.: Variations of Indian and African monsoons induced by insolation changes at 6 and $9.5 \mathrm{kyr} \mathrm{BP}$, Clim. Dynam., 33, 215-231, 2009.

McGlone, M. S., Kershaw, A. P., and Markgraf, V.: El Niño/ Southern Oscillation climatic variability in Australasian and South American paleoenvironmental records. In El Niño - historical and paleoclimatic aspects of the Southern Oscillation, edited by: Diaz, H. F. and Markgraf, V., Cambridge Univ. Press, New York, 435-462, 1992.

McGregor, H. V. and Gagan, M. K.: Western Pacific coral $\delta^{18} \mathrm{O}$ records of anomalous Holocene variability in the $\mathrm{El}$ Niño-Southern Oscillation, Geophys. Res. Lett., 31, L11204, doi:10.1029/2004GL019972, 2004.

Meehl, G. A., Gent, P. R., Arblaster, J. M., Otto-Bliesner, B. L., Brady, E. C., and Craig, A.: Factors that affect the amplitude of El Niño in global coupled climate models, Clim. Dynam., 17, 515-526, 2001.

Meehl, G. A., Stocker, T. F., Collins, W. D., Friedlingstein, P., Gaye, A. T., Gregory, J. M., Kitoh, A., Knutti, R., Murphy, J. M., Noda, A., Raper, S. C. B., Watterson, I. G., Weaver, A. J., and Zhao, Z. C.: Global climate projections. Climate Change 2007: The Physical Science Basis. Contribution of Working Croup I to the Fourth Assessment Report of the Intergovernmental Panel on Climate Change, edited by: Solomon, S., Qin, D., Manning, M., Chen, Z., Marquis, M., Averyt, K. B., Tignor, M., and Miller, H. L., Cambridge University Press, Cambridge, United Kingdom and New York, NY, USA, 2007.

Merryfield, W. J.: Changes to ENSO under $\mathrm{CO}_{2}$ doubling in the IPCC AR4 coupled climate models, J. Climate, 19, 4009-4027, 2006.

Moy, C. M., Seltzer, G. O., Rodbell, D. T., and Anderson, D. M.: Variability of El Niño/Southern Oscillation activity at millennial time-scales during the Holocene epoch, Nature, 420, 162-165, 2002.

Otto-Bliesner, B. L. and Brady, E. C.: Tropical Pacific variability in the NCAR Climate System Model, J. Climate, 14, 3587-3607, 2001.

Otto-Bliesner, B. L., Brady, E. C., Shin, S.-I., Liu, Z., and Shields, C.: Modeling El Niño and its tropical teleconnections during the last glacial-interglacial cycle, Geophys. Res. Lett., 30, 21982201, 2003.

Philander, S. G.: El Niño, La Niña, and the Southern Oscillation, Academic Press, San Diego, ix+293 pp., 1990.

Rayner, N. A., Parker, D. E., Horton, E. B., Folland, C. K., Alexander, L. V., Rowell, D. P., Kent, E. C., and Kaplan, A.: Global analyses of sea surface temperature, sea ice, and night marine air temperature since the late nineteenth century, J. Geophys. Res., 108, 4407, doi:10.1029/2002JD002670, 2003. 
Reichler, T. and Kim, J.: How well do coupled models simulate today's climate?, B. Am. Meteorol. Soc., 89, 303-311, 2008.

Rodbell, D. T., Seltzer, G. O., Anderson, D. M., Abbott, M. B., Enfield, D. B., and Newman, J. H.: An 15,000-year Record of El Niño-Driven Alluviation in Southwestern Ecuador, Science, 283, 516-520, 1999.

Ropelewski, C. F. and Halpert, M. S.: North American precipitation and temperature patterns associated with the El Niño/Southern Oscillation (ENSO), Mon. Weather Rev., 114, 2352-2362, 1986.

Sandweiss, D. H., Richardson, J. B., Reitz, E. J., Rollins, H. B., and Maasch, K. A.: Geoarchaeological evidence from Peru for a 5000 year B.P. onset of El Niño, Science, 273, 1531-1533, 1996.

Solomon, S., Qin, D., Manning, M., Chen, Z., Marquis, M., Averyt, K. B., Tignor, M., and Miller, H. L. (Eds.): IPCC 2007: Climate Change 2007, The physical basis. Contribution of Working Group I to the Fourth Assessment Report of the Intergovernmental Panel on Climate change, Cambridge University Press, Cambridge, 2007.

Stott, L., Cannariato, K., Thunell, R., Haug, G. H., Koutavas, A., and Lund, S.: Decline of surface temperature and salinity in the western tropical Pacific Ocean in the Holocene epoch, Nature, 431, 56-59, 2004.

Terray, L., Sevault, E., Guilyardi, E., and Thual, O.: The OASIS coupler user guide version 2.0. Cerfacs technical report TR/CMGC/95-46, 123 pp., 1995.

Timmermann, A., Lorenz, S. J., An, S.-I., Clement, A., and Xie, S.-P.: The Effect of Orbital Forcing on the Mean Climate and Variability of the Tropical Pacific, J. Climate, 20, 4147-4259, 2007.

Tudhope, A. W., Chilcott, C. P., McCulloch, M. T., Cook, E. R., Chappell, J., Ellam, R. M., Lea, D. W., Lough, J. M., and Shimmield, G. B.: Variability in the El Niño-Southern Oscillation through a glacial-interglacial cycle, Science, 291, 1511-1517, 2001.

van Oldenborgh, G. J., Philip, S. Y., and Collins, M.: El Niño in a changing climate: a multi-model study, Ocean Sci., 1, 81-95, doi:10.5194/os-1-81-2005, 2005.
Wang, B.: The vertical structure and development of the ENSO anomaly mode during 1979-1989, J. Atmos. Sci., 49, 698-712, 1992.

Wang, B., Wu, R., and Fu, X.: Pacific-East Asian Teleconnection: How Does ENSO Affect East Asian Climate?, J. Climate, 13, 1517-1536, 2000.

Wang, C. and Picaut, J.: Understanding ENSO physics - A review. Earth's Climate: The Ocean-Atmosphere Interaction, Geophy. Monog., 147, 21-48, 2004.

Wanner, H., Beer, J., Butikofer, J., Crowley, T. J., Cubasch, U., Fluckiger, J., Goosse, H., Grosjean, M., Joos, F., Kaplan, J. O., Kuttel, M., Muller, S. A., Prentice, I. C., Solomina, O., Stocker, T. F., Tarasov, P., Wagner, M., and Widmann, M.: Mid- to Late Holocene climate change: an overview, Quaternary Sci. Rev., 27, 1791-1828, 2008.

Wright, H., Kutzbach, J., Webb III, T., Ruddiman, W., Street-Perrot, F., Bartlein, P. (Eds.): Global climates since the last glacial maximum, University of Minnesota Press, 1993.

Xie, S.-P., Okumura, Y., Miyama, T., and Timmermann, A.: Influences of Atlantic climate change on the tropical Pacific via the Central American Isthmus, J. Climate, 21, 3914-3928, 2008.

Yeh, S.-W., Kug, J.-S., Dewitte, B., Kwon, M.-H., Kirtman, B. P., and Jin, F.-F.: El Niño in a changing climate, Nature, 461, 511674, 2009.

Zebiak, S. E. and Cane, M. A.: A model El Niño-Southern Oscillation, Mon. Weather Rev., 115, 2262-2278, 1987.

Zhang, Y., Rossow, W. B., Lacis, A. A., Oinas, V., and Mishchenko, M. I.: Calculation of radiative fluxes from the surface to top of atmosphere based on ISCCP and other global data sets: Refinements of the radiative transfer model and the input data, J. Geophys. Res., 109, doi:10.1029/2003JD004457, 2004.

Zheng, W., Braconnot, P., Guilyardi, E., Merkel, U., and Yu, Y.: ENSO at $6 \mathrm{ka}$ and $21 \mathrm{ka}$ from ocean-atmosphere coupled model simulations, Clim. Dynam., 30, 745-762, 2008. 